\title{
Prognostic and predictive value of tumor-infiltrating Iymphocytes for clinical therapeutic research in patients with non-small cell lung cancer
}

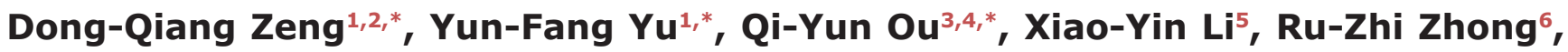 \\ Chuan-Miao Xie ${ }^{4}$, Qiu-Gen Hu${ }^{1}$ \\ ${ }^{1}$ Department of Radiology, Affiliated Shunde First People's Hospital of Southern Medical University, Foshan, Guangdong, \\ P. R. China \\ ${ }^{2}$ School of Basic Medical Sciences, Southern Medical University, Guangzhou, Guangdong, P. R. China \\ ${ }^{3}$ Department of Ultrasound, Affiliated Shunde First People's Hospital of Southern Medical University, Foshan, Guangdong, \\ P. R. China \\ ${ }^{4}$ Imaging Diagnostic and Interventional Center, Sun Yat-sen University Cancer Center, State Key Laboratory of Oncology in \\ South China, Collaborative Innovation Center for Cancer Medicine, Guangzhou, Guangdong, P. R. China \\ ${ }^{5}$ Department of Medical Oncology, Nanfang Hospital, Southern Medical University, Guangzhou, Guangdong, P. R. China \\ ${ }^{6}$ Guangdong Agricultural Reclamation Central Hospital, Affiliated Zhanjiang Cancer Hospital of Guangdong Medical University, \\ Zhanjiang, Guangdong, P. R. China \\ *These authors have contributed equally to this work and were co-first authors \\ Correspondence to: Qiu-Gen Hu, e-mail: hqiugen@126.com \\ Chuan-Miao Xie, e-mail: xchuanm@126.com \\ Keywords: meta-analysis, molecular subtypes, non-small cell lung cancer, survival, tumor-infiltrating lymphocytes \\ Received: November 09, $2015 \quad$ Accepted: January 28, $2016 \quad$ Published: February 09, 2016
}

\section{ABSTRACT}

Background: Previous preclinical and clinical studies have shown that levels of tumor-infiltrating lymphocytes (TILs) significantly correlated with prognosis in non-small cell lung cancer (NSCLC), and survival after therapy; however, this finding remains controversial. We performed a meta-analysis, to evaluate, systematically, the clinical utilization of TIL subtypes in patients with NSCLC.

Methods: The PubMed, ISI Web of Science, EMBASE, and Cochrane Library databases were searched to identify relevant studies. We pooled estimates of treatment effects, and hazards were summarized using random or fixed effects models to evaluate survival outcomes.

Results: A total of 24 relevant studies involving 7,006 patients were eligible. The median percentage of lymph node positivity was $45.7 \%$ ( $95 \%$ confidence interval [CI], 37.1-56.4\%). Pooled analysis shows that high levels of CD8 ${ }^{+}$TILs had a good prognostic effect on survival with a hazard ratio $(H R)$ of $0.91(P=0.013)$ for death and $0.74(P=0.001)$ for recurrence, as did high levels of $\mathrm{CD3}^{+}$and $C D 4^{+}$TILs, with HRs of $0.77(P=0.009)$ and $0.78(P=0.005)$ for death, respectively. By contrast, high levels of FoxP3 ${ }^{+}$regulatory TILs had a worse prognostic effect for overall and recurrencefree survival, with HRs of $1.69(P=0.042)$ and $1.79(P=0.001)$, respectively. No individual study affected the results, and no publication bias was found.

Conclusions: Our findings support the hypothesis that TILs could be a prognostic marker in NSCLC. High-quality randomized studies are needed to verify statistically the effect of TILs on prognosis in future research.

\section{INTRODUCTION}

The host immune response has been demonstrated to be crucial for cancer invasion, progression, and subsequent metastasis [1,2]. Furthermore, preclinical data suggest that a clinically relevant immunoadjuvant pathway can trigger an antitumor immune response, by causing an immunogenic cell death that allows antigen cross-presentation and 
activation of tumor-specific cytotoxic T cells $[3,4]$. In particular, the intensity of the tumoral immune response influences the effectiveness of cancer therapy; levels of tumor-infiltrating lymphocytes (TILs), such as $\mathrm{CD}^{+}$, $\mathrm{CD}^{+}, \mathrm{CD}^{+}$, and factor forkhead box $\mathrm{P} 3\left(\mathrm{FoxP}^{+}\right) \mathrm{T}$ cells were proved to be an expression of immune response that is associated with patient survival in a wide variety of tumor types [5-8]. Recently, new therapies that reactivate anticancer immune responses, for example, in breast cancer [9] and colorectal cancer [10], have entered clinical practice and have favorably improved outcomes. Similarly, TILs are a predictive biomarker of response to neoadjuvant chemotherapy in non-small cell lung cancer (NSCLC) [11].

In NSCLC, histological subtyping has been mostly relevant to clinicopathological variables for routine prognosis and treatment [12]. Tumor-infiltrating lymphocytes have been described to predominate in aggressive NSCLC diseases, such as adenocarcinoma $[13,14]$, squamous cell carcinoma [15], and large cell carcinoma [16]. Also reported is the high expression of TILs in the NSCLC, a subset with a known favorable prognosis $[17,18]$. Nonetheless, the literature reveals that the characterization of TILs in the prognosis of patients with NSCLC is still debatable. The discordance in these results is mainly due to the substantial diversity in study design, assay methods, patient population, histological subtypes, immunological response involved, and methods and criteria used to qualify and quantify the immune response.

To date, a number of reports [13-16, 19-38] have informed that the subtype of TILs, and the density or location of the tumor are correlated with the survival of NSCLC. In an attempt to resolve such inconsistencies, as well as to uncover more accurate prognostic biomarkers, we conducted a metaanalysis of the existing data to evaluate, systematically, the clinical utility of TILs in NSCLC. Since many studies identified TILs by $\mathrm{CD}^{+}, \mathrm{CD}^{+}, \mathrm{CD}^{+}$, and $\mathrm{FoxP}^{+}$, we also analyzed the predictive value of these TILs subtypes, as well as of the ratios between these subsets in NSCLC.

\section{RESULTS}

\section{Identification of eligible studies}

A total of 14,961 potential articles were uploaded from PubMed, the ISI Web of Science, EMBASE, and the Cochrane Library. Of these, 14,133 articles were excluded because they did not satisfy all the inclusion criteria. The majority of these articles were excluded after reviewing the titles and abstracts because they were abstracts of nonoutcome related studies, studies of other diseases, studies that were not related to TILs, studies of mouse models or cell lines, case or committee reports, review articles and metaanalyses, duplicate publications, or otherwise not related to studies evaluating the predictive roles of TILs in NSCLC. A total of 71 articles remained for full-text review. In the review, 47 articles were excluded for the following reasons: 5 articles were review articles, comments, or letters, 31 articles had insufficient data, 3 articles had no relevant outcomes, and 8 articles were studies of peripheral blood lymphocyte. Finally, 24 articles [13-16, 19-38] were included in the current metaanalysis. A summary of the article selection process is shown in Figure 1.

\section{Study characteristics}

Characteristics of the 24 eligible studies are mainly summarized in Table 1 . These studies were published between 2003 and 2015. Six studies [21, 25, 30, 35, 37, $38]$ concerned $\mathrm{CD}^{+} \mathrm{T}$ lymphocytes, six studies $[14,16$, $19,22,28,33]$ were of $\mathrm{CD}^{+} \mathrm{T}$ lymphocytes, and six studies reported on FoxP3 $3^{+} \mathrm{T}$ lymphocytes $[13,21,27$, $31,33,34]$. The TILs ratio was reported in five studies, including both $\mathrm{CD}^{+} / \mathrm{CD}^{+}$ratio $[16,22,32]$ and $\mathrm{FoxP}^{+} /$ $\mathrm{CD}^{+}$ratio $[13,21]$, and 16 studies [14-16, 19, 20, 22-24, $26,28,29,33,35-38]$ considered $\mathrm{CD} 8^{+} \mathrm{T}$ lymphocytes, which was the most popular lymphocyte marker. The total sample size from all studies was 7,006, with a mean of 280 patients (95\% confidence interval [CI], 170-412 patients) per study. Most of the studies were performed in Asia ( $n$ $=12)$. Others were conducted in Europe $(n=8)$, North America $(n=3)$, and South America $(n=1)$. Nine studies included fewer than 100 patients, while nine further studies enrolled $>200$ patients. The median percentage of positive lymph nodes, ranging from $26 \%$ to $100 \%$ in 18 reporting studies, was $45.7 \%$ (95\% CI, 37.1-56.4\%). The densities of TILs in intratumoral sites, stromal sites, and both sites combined were reported in 5 studies, 7 studies, and 14 studies, respectively. The most frequently used cutoff values for high versus low or positive verus negative density of TILs were the median $(n=8)$, and the staining score $(n=6)$.

\section{Overall meta-analysis}

\section{CD8 $^{+} \mathrm{T}$ lymphocytes}

A total of 17 eligible studies were pooled for analysis of the density of $\mathrm{CD} 8^{+} \mathrm{T}$ lymphocytes as a prognostic and predictive marker in NSCLC; this analysis included 5,113 patients. Figure 2A indicates that high levels of $\mathrm{CD} 8^{+} \mathrm{T}$ lymphocytes indicate a good prognosis for overall survival (hazard ratio $[\mathrm{HR}]=0.91 ; 95 \% \mathrm{CI}$, $\left.0.84-0.98 ; P_{\mathrm{HR}}=0.013\right)$, disease-specific survival ( $\mathrm{HR}=$ $\left.0.57 ; 95 \% \mathrm{CI}, 0.39-0.83 ; P_{\mathrm{HR}}=0.004\right)$, and recurrence- or disease-free survival $\left(\mathrm{HR}=0.74 ; 95 \% \mathrm{CI}, 0.61-0.89 ; P_{\mathrm{HR}}\right.$ $=0.001)$. Egger's test $(P=0.285)$ and Begg's test $(P=$ 0.284 ), as well as a funnel plot (see Figure $3 \mathrm{~A}$ ), provided no evidence of publication bias for overall survival. However, significant heterogeneity was noted for overall survival $\left(R^{2}=78.3 \%, P=0.000\right)$.

Meta-sensitivity analysis did not suggest undue influence of any single study. Therefore, we performed 
six predefined subgroup analyses to evaluate the effect of various clinical variables on pooled overall survival (see Figure 2B). These analyses revealed that high levels of $\mathrm{CD}^{+} \mathrm{T}$ lymphocytes were associated with improved overall survival in studies with large numbers of patients $(\geq 200$; HR $=0.73 ; 95 \% \mathrm{CI}, 0.63-0.83)$, histology subtype $(\mathrm{HR}=0.68$; $95 \% \mathrm{CI}, 0.54-0.86$ for squamous cell carcinoma; and HR = 0.92; 95\% CI, 0.85-0.99 for NSCLCs), European patients $(\mathrm{HR}=0.76 ; 95 \% \mathrm{CI}, 0.65-0.88)$. Any difference in these studies might be due to insufficient controls to confound for number of patients, histology subtype, region, percentage of men, or percentage of positive lymph nodes.

\section{$\mathrm{CD3}^{+} \mathrm{T}$ lymphocytes}

Six studies, involving 1,503 patients, investigated the association between the infiltration of $\mathrm{CD}^{+} \mathrm{T}$ lymphocytes and survival for patients with NSCLC. Pooled HRs and 95\% CIs pointed to a survival advantage associated with high levels of $\mathrm{CD}^{+} \mathrm{T}$ lymphocytes, with improved overall survival $(\mathrm{HR}=0.77 ; 95 \% \mathrm{CI}, 0.63-$ $\left.0.94 ; P_{\mathrm{HR}}=0.009\right)$ and disease-specific survival $(\mathrm{HR}=$ $0.57 ; 95 \%$ CI, 0.41-0.78; $P_{\mathrm{HR}}=0.001$ ), but no significant correlation was found for recurrence- or disease-free survival $\left(\mathrm{HR}=0.91 ; 95 \% \mathrm{CI}, 0.81-1.02 ; P_{\mathrm{HR}}=0.115\right)$. These results are shown in Figure 4A.

We wondered whether a number of clinical variables would affect overall survival, and moderate heterogeneity was noted $\left(I^{2}=24.4 \%, P=0.227\right)$. Therefore, subgroup analyses were carried out for overall survival (see Figure 4B). Exploratory subgroup analysis suggests that all patients benefit from high levels of $\mathrm{CD}^{+} \mathrm{T}$ lymphocytes with respect to location of both sites (intratumoral and stromal; HR $=0.69 ; 95 \%$ CI, 0.48-0.99); large number of patients $(\geq 200 ; \mathrm{HR}=0.75 ; 95 \% \mathrm{CI}, 0.61-0.92)$, histology subtype (NSCLCs; HR $=0.76 ; 95 \%$ CI, 0.62-0.92), percentage of men $(\geq 70 \%$; HR $=0.80 ; 95 \% \mathrm{CI}, 0.65-$ $0.98)$. There was no evidence of a difference in treatment effects between any of the subgroups.

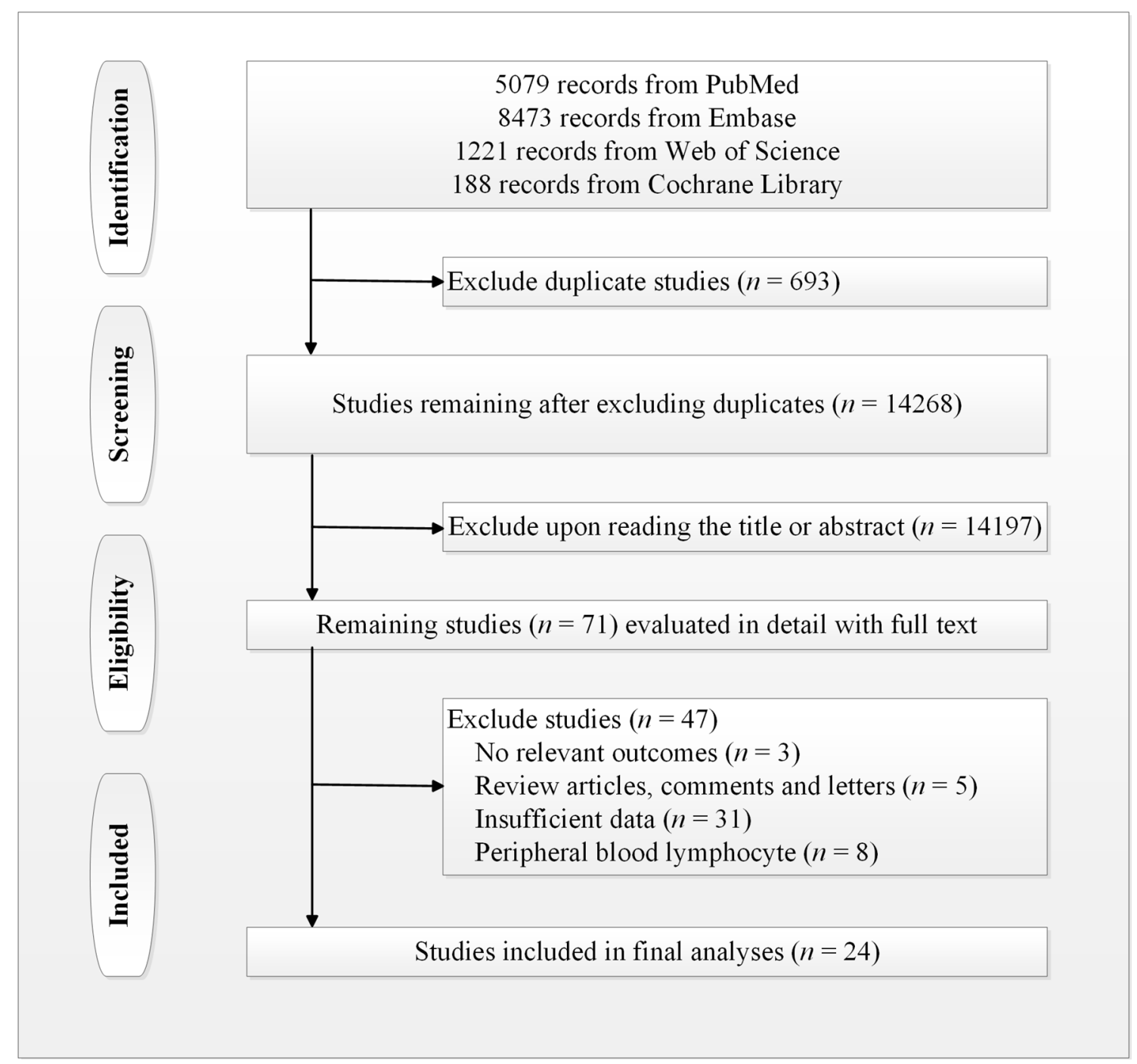

Figure 1: Study selection flow chart of eligible publications. 
Table 1: Characteristics of the included studies

\begin{tabular}{|c|c|c|c|c|c|c|c|c|c|c|}
\hline No & Study/Year & Ethnicity & $\begin{array}{c}\text { No. of } \\
\text { Patient } \\
\text { (male,\%) }\end{array}$ & $\begin{array}{l}\text { Tumor } \\
\text { stage }\end{array}$ & $\begin{array}{l}\text { Histologic } \\
\text { subtype }\end{array}$ & $\begin{array}{c}\%, \\
\text { Positive } \\
\text { lymph } \\
\text { nodes }\end{array}$ & $\begin{array}{c}\text { TILs } \\
\text { phenotype }\end{array}$ & Location & $\begin{array}{l}\text { Definition } \\
\text { of rich TILs }\end{array}$ & Outcomes \\
\hline 1 & $\begin{array}{c}\text { Wakabayashi } \\
2003 \text { [19] }\end{array}$ & Asia & $\begin{array}{l}178 \\
(66 \%)\end{array}$ & $\begin{array}{l}\text { I:60\%, } \\
\text { II: } 13 \%, \\
\text { III:27\% }\end{array}$ & $\begin{array}{l}\text { ADC: } 53 \%, \\
\text { SCC: } 47 \%\end{array}$ & $36 \%$ & $\mathrm{CD}^{+}, \mathrm{CD}^{+}$ & IS,SS & median & OS \\
\hline 2 & $\begin{array}{c}\text { Hiraoka } 2006 \\
{[16]}\end{array}$ & Asia & $\begin{array}{l}109 \\
(65 \%)\end{array}$ & $\begin{array}{l}\text { I:61\%, II- } \\
\text { III:39\% }\end{array}$ & $\begin{array}{l}\text { ADC: } 53 \% \text {, } \\
\text { SCC: } 36 \% \\
\text { LCC: } 7 \%, \\
\text { others: } 4 \%\end{array}$ & $29 \%$ & $\begin{array}{c}\mathrm{CD}^{+}, \\
\mathrm{CD}^{+}, \\
\mathrm{CD}^{+} / \mathrm{CD}^{+} \\
\text {ratio }\end{array}$ & SS & $\geq 5 / \mathrm{HPF}$ & OS \\
\hline 3 & $\begin{array}{c}\text { Ikeda } 2006 \\
{[20]}\end{array}$ & Asia & $83,(78 \%)$ & $\begin{array}{l}\text { I:48\%, II- } \\
\text { III: } 52 \%\end{array}$ & $\begin{array}{c}\text { ADC: } 59 \% \text {, } \\
\text { SCC: } 28 \%, \\
\text { others: } 13 \%\end{array}$ & $45 \%$ & $\mathrm{CD}^{+}$ & IS+SS & $\begin{array}{c}\text { TILs: } \geq 50 / \\
\text { HPF } \\
\text { CD8: } \geq 5 / \\
\text { HPF }\end{array}$ & OS \\
\hline 4 & $\begin{array}{l}\text { Petersen } \\
2006[21]\end{array}$ & $\begin{array}{l}\text { North } \\
\text { America }\end{array}$ & $64,(53 \%)$ & I: $100 \%$ & $\begin{array}{l}\text { ADC: } 47 \% \text {, } \\
\text { SCC: } 34 \%, \\
\text { others: } 19 \%\end{array}$ & NR & $\begin{array}{l}\mathrm{CD}^{+} \text {, } \\
\text { FoxP3 }^{+} \text {, } \\
\text { FoxP3 }^{+} / \\
\mathrm{CD}^{+} \text {ratio }\end{array}$ & SS & $\begin{array}{l}\text { median, } \\
\text { Score } \geq 2\end{array}$ & RFS \\
\hline 5 & $\begin{array}{l}\text { Al-Shibli } \\
2008 \text { [22] }\end{array}$ & Europe & $\begin{array}{l}335 \\
(75 \%)\end{array}$ & $\begin{array}{l}\text { I:63\%, } \\
\text { II:27\%, } \\
\text { III: } 10 \%\end{array}$ & $\begin{array}{c}\text { ADC: } 28 \%, \\
\text { SCC: } 57 \%, \\
\text { LCC: } 9 \%\end{array}$ & $31 \%$ & $\begin{array}{c}\mathrm{CD}^{+}{ }^{+} \\
\mathrm{CD}^{+}, \\
\mathrm{CD} 4^{+} / \mathrm{CD} 8^{+} \\
\text {ratio }\end{array}$ & $\mathrm{IS}+\mathrm{SS}$ & $\begin{array}{c}\text { CD4:IS:5\%, } \\
\text { SS: } 25 \% \\
\text { CD8:IS:5\%, } \\
\text { SS:50\% }\end{array}$ & DSS \\
\hline 6 & $\begin{array}{c}\text { Kawai } 2008 \\
{[23]}\end{array}$ & Asia & $\begin{array}{c}199 \\
(70 \%)\end{array}$ & IV: $100 \%$ & $\begin{array}{c}\text { ADC: } 67.3 \% \\
\text { SCC: } 20.6 \% \\
\text { others: } 12 \%\end{array}$ & $100 \%$ & $\mathrm{CD}^{+}$ & IS,SS & median & OS \\
\hline 7 & $\begin{array}{l}\text { Ruffini } 2008 \\
\text { [24] }\end{array}$ & Europe & $\begin{array}{l}1290 \\
(84 \%)\end{array}$ & $\begin{array}{l}\text { I:55\%, } \\
\text { II: } 21 \%, \\
\text { IIIa: } 16 \%\end{array}$ & $\begin{array}{l}\text { ADC: } 38 \% \text {, } \\
\text { SCC: } 43 \% \\
\text { LCC: } 4 \% \text {, } \\
\text { others: } 15 \%\end{array}$ & $33 \%$ & $\mathrm{CD}^{+}$ & IS & $\begin{array}{l}1 \geq \text { positive } \\
\text { staining in } \\
\geq 20 \% \text { of } \\
\text { cells }\end{array}$ & OS \\
\hline 8 & $\begin{array}{l}\text { Al-Shibli } \\
2010[25]\end{array}$ & Europe & $\begin{array}{l}335 \\
(75 \%)\end{array}$ & $\begin{array}{l}\text { I:63\%, } \\
\text { II:27\%, } \\
\text { III: } 10 \%\end{array}$ & $\begin{array}{c}\text { ADC: } 28 \%, \\
\text { SCC: } 57 \%, \\
\text { LCC: } 9 \%\end{array}$ & $31 \%$ & $\mathrm{CD}^{+}$ & IS+SS & $\begin{array}{l}\text { IS: } \geq 1 \%, \\
\text { SS: } \geq 50 \%\end{array}$ & DSS \\
\hline 9 & $\begin{array}{l}\text { Dai } 2010 \\
\quad[26]\end{array}$ & Asia & $99,(80 \%)$ & $\begin{array}{l}\text { I:35\%, } \\
\text { II:20\%, } \\
\text { III: } 34 \%, \\
\text { IV: } 10 \%\end{array}$ & $\begin{array}{c}\text { ADC: } 45 \%, \\
\text { SCC: } 51 \%, \\
\text { LCC: } 4 \%\end{array}$ & $40 \%$ & $\mathrm{CD}^{+}$ & IS+SS & median & OS \\
\hline 10 & $\begin{array}{c}\text { Shimizu } 2010 \\
{[27]}\end{array}$ & Asia & $\begin{array}{c}100 \\
(60 \%)\end{array}$ & $\begin{array}{l}\text { I:68\%, } \\
\text { II:14\%, } \\
\text { III:18\% }\end{array}$ & $\begin{array}{l}\text { ADC: } 69 \%, \\
\text { SCC: } 31 \%\end{array}$ & $26 \%$ & FoxP3 $^{+}$ & $\mathrm{IS}+\mathrm{SS}$ & $\mathrm{HPF} \geq 3$ & RFS \\
\hline 11 & $\begin{array}{c}\text { da Costa } \\
\text { Souza } 2012 \\
{[28]}\end{array}$ & $\begin{array}{c}\text { South } \\
\text { America }\end{array}$ & $65,(60 \%)$ & $\begin{array}{l}\text { I:31\%, } \\
\text { II:51\% } \\
\text { III:19\% }\end{array}$ & $\begin{array}{l}\text { ADC: } 58 \%, \\
\text { SCC: } 31 \%, \\
\text { LCC: } 11 \%\end{array}$ & $40 \%$ & $\mathrm{CD}^{+}, \mathrm{CD}^{+}$ & IS+SS & $\begin{array}{c}\text { CD } 8>1.8 \% \\
\text { CD } 4 \\
>16.1 \%\end{array}$ & OS \\
\hline 12 & Ilie 2012 [29] & Europe & $\begin{array}{l}632 \\
(74 \%)\end{array}$ & $\begin{array}{l}\text { I:39\%, } \\
\text { II:29\%, } \\
\text { III: } 27 \%\end{array}$ & $\begin{array}{c}\text { ADC: } 55 \%, \\
\text { SCC: } 33 \%, \\
\text { LCC: } 4 \%\end{array}$ & NR & $\mathrm{CD} 8^{+}$ & IS & median & OS \\
\hline 13 & $\begin{array}{c}\text { Kayser } 2012 \\
{[30]}\end{array}$ & Europe & $\begin{array}{l}232 \\
(72 \%)\end{array}$ & $\begin{array}{c}\text { I:39\%, } \\
\text { II:26\%, } \\
\text { III: } 33 \%, \\
\text { IV:2\% }\end{array}$ & $\begin{array}{c}\text { ADC: } 32.3 \%, \\
\text { SCC: } 40.1 \%, \\
\text { LCC: } 27.6 \%\end{array}$ & $43 \%$ & $\mathrm{CD}^{+}$ & $\mathrm{IS}+\mathrm{SS}$ & median & OS \\
\hline 14 & $\begin{array}{c}\text { Tao } 2012 \\
{[31]}\end{array}$ & Asia & $87,(64 \%)$ & NR & $\begin{array}{l}\text { ADC: } 70 \%, \\
\text { SCC: } 23 \%, \\
\text { LCC: } 4 \%, \\
\text { others:3\% }\end{array}$ & $29 \%$ & FoxP3 $^{+}$ & SS & $\mathrm{HPF} \geq 25$ & $\begin{array}{c}\text { OS } \\
\text { (Continued) }\end{array}$ \\
\hline
\end{tabular}




\begin{tabular}{|c|c|c|c|c|c|c|c|c|c|c|}
\hline No & Study/Year & Ethnicity & $\begin{array}{c}\text { No. of } \\
\text { Patient } \\
\text { (male,\%) }\end{array}$ & $\begin{array}{l}\text { Tumor } \\
\text { stage }\end{array}$ & $\begin{array}{l}\text { Histologic } \\
\text { subtype }\end{array}$ & $\begin{array}{c}\%, \\
\text { Positive } \\
\text { lymph } \\
\text { nodes }\end{array}$ & $\begin{array}{c}\text { TILs } \\
\text { phenotype }\end{array}$ & Location & $\begin{array}{l}\text { Definition } \\
\text { of rich TILs }\end{array}$ & Outcomes \\
\hline 15 & $\begin{array}{l}\text { Hald } 2012 \\
{[32]}\end{array}$ & Europe & $55,(69 \%)$ & $\begin{array}{l}\mathrm{I}: 13 \%, \\
\text { II:36\%, } \\
\text { III:51\% }\end{array}$ & $\begin{array}{l}\text { ADC: } 29 \%, \\
\text { SCC: } 60 \%, \\
\text { LCC: } 11 \%\end{array}$ & $75 \%$ & $\begin{array}{c}\mathrm{CD}^{+} / \mathrm{CD}^{+} \\
\text {ratio }\end{array}$ & SS & $\begin{array}{c}\text { CD4:IS:5\%, } \\
\text { SS: } 25 \% \\
\text { CD8:IS:5\%, } \\
\text { SS:50\% }\end{array}$ & OS \\
\hline 16 & $\begin{array}{c}\text { Suziki } 2013 \\
\text { [13] }\end{array}$ & $\begin{array}{c}\text { North } \\
\text { America }\end{array}$ & $\begin{array}{c}956 \\
(38 \%)\end{array}$ & $\mathrm{I}: 100 \%$ & ADC: $100 \%$ & $70 \%$ & $\begin{array}{c}\text { FoxP3 }^{+} \\
\text {FoxP3 }^{+} / \\
\mathrm{CD}^{+} \text {ratio }\end{array}$ & SS & Score $\geq 2$ & RFS \\
\hline 17 & $\begin{array}{l}\text { Hasegawa } \\
2014 \text { [33] }\end{array}$ & Asia & $67,(66 \%)$ & $\begin{array}{l}\text { I: } 70.2 \%, \\
\text { II: } 10.5 \%, \\
\text { III: } 19.3 \%\end{array}$ & $\begin{array}{c}\text { ADC: } 67.2 \% \text {, } \\
\text { SCC: } 23.8 \%, \\
\text { others: } 9 \%\end{array}$ & $75 \%$ & $\begin{array}{l}\mathrm{CD}^{+} \\
\mathrm{CD}^{+} \\
\text {FoxP3 }^{+}\end{array}$ & IS + SS & $\geq 3 / \mathrm{HPF}$ & RFS \\
\hline 18 & $\begin{array}{c}\text { Tao } 2014 \\
{[34]}\end{array}$ & Asia & $64,(84 \%)$ & $\begin{array}{l}\text { II: } 17 \%, \\
\text { III: } 83 \%\end{array}$ & $\begin{array}{l}\text { ADC: } 48 \%, \\
\text { SCC: } 45 \%, \\
\text { others: } 7 \%\end{array}$ & $30 \%$ & FoxP3 $^{+}$ & IS + SS & median & OS, RFS \\
\hline 19 & $\begin{array}{c}\text { Djenidi } 2015 \\
{[35]}\end{array}$ & Europe & $\begin{array}{c}191 \\
(51 \%)\end{array}$ & $\mathrm{I}: 100 \%$ & $\begin{array}{c}\text { ADC: } 45.5 \% \text {, } \\
\text { SCC: } 41.9 \% \text {, } \\
\text { others: } 12.6 \%\end{array}$ & NR & $\begin{array}{l}\mathrm{CD}^{+} \\
\mathrm{CD}^{+}\end{array}$ & IS + SS & median & DFS \\
\hline 20 & $\begin{array}{l}\text { Donnem } \\
2015 \text { [36] }\end{array}$ & Europe & 797 & $\begin{array}{l}\text { I:50\%, } \\
\text { II:34\%, } \\
\text { III: } 16 \%\end{array}$ & $\begin{array}{l}\text { ADC: } 47 \%, \\
\text { SCC: } 43.8 \% \text {, } \\
\text { others: } 9.2 \%\end{array}$ & NR & $\mathrm{CD}^{+}$ & SS & $\begin{array}{l}\text { Low: } \leq 25 \% \\
\text { high: }>50 \%\end{array}$ & $\begin{array}{l}\text { OS,DSS, } \\
\text { DFS }\end{array}$ \\
\hline \multirow[t]{2}{*}{21} & $\begin{array}{l}\text { Schalper } \\
2015 \text { [37] }\end{array}$ & $\begin{array}{l}\text { North } \\
\text { America }\end{array}$ & $\begin{array}{l}\text { a: } 202, \\
(51 \%)\end{array}$ & $\begin{array}{c}\text { I-II: } 68 \%, \\
\text { III- } \\
\text { IV:32\% }\end{array}$ & $\begin{array}{l}\text { ADC: } 60 \% \text {, } \\
\text { SCC: } 17 \%, \\
\text { others: } 23 \%\end{array}$ & NR & $\mathrm{CD}^{+}, \mathrm{CD}^{+}$ & IS + SS & Score $\geq 3$ & OS \\
\hline & & & $\begin{array}{l}\text { b: } 350, \\
(88 \%)\end{array}$ & $\begin{array}{c}\text { I-II: } 60 \%, \\
\text { III- } \\
\text { IV: } 40 \%\end{array}$ & $\begin{array}{l}\text { ADC: } 39 \% \\
\text { SCC: } 48 \%, \\
\text { others: } 13 \%\end{array}$ & NR & $\mathrm{CD}^{+}, \mathrm{CD}^{+}$ & IS + SS & Score $\geq 3$ & OS \\
\hline 22 & $\underset{[15]}{\operatorname{Kim} 2015}$ & Asia & $\begin{array}{l}331 \\
(96 \%)\end{array}$ & $\begin{array}{l}\text { I:40\%, } \\
\text { II: } 36 \%, \\
\text { III: } 24 \%\end{array}$ & SCC: $100 \%$ & $42 \%$ & $\mathrm{CD}^{+}$ & IS + SS & median & OS, DFS \\
\hline 23 & Lin 2015 [14] & Asia & $\begin{array}{c}56, \\
(37.5 \%)\end{array}$ & NR & ADC: $100 \%$ & NR & $\mathrm{CD}^{+}, \mathrm{CD}^{+}$ & IS & Score $\geq 2$ & OS, RFS \\
\hline 24 & $\begin{array}{c}\text { Tian } 2015 \\
{[38]}\end{array}$ & Asia & $\begin{array}{c}129 \\
(30 \%)\end{array}$ & $\begin{array}{l}\text { I: } 37.2 \%, \\
\text { II: } 22.4 \% \\
\text { III: } 40.3 \%\end{array}$ & $\begin{array}{l}\text { ADC: } 37.21 \% \\
\text { SCC: } 47.29 \% \\
\text { others: } 15.5 \%\end{array}$ & $48 \%$ & $\mathrm{CD}^{+}, \mathrm{CD}^{+}$ & $\mathrm{IS}+\mathrm{SS}$ & Score $\geq 3$ & OS \\
\hline
\end{tabular}

Abbreviations: $\mathrm{ADC}=$ adenocarcinoma; $\mathrm{SCC}=$ squamous cell carcinoma; $\mathrm{LCC}=$ large cell carcinoma; $\mathrm{NSCLC}=$ non-small cell lung cancer; HPF=high-power fields; IS=Intratumoral sites; $\mathrm{SS}=$ stromal sites; TILs=tumor-infiltrating lymphocytes; $\mathrm{NR}=$ no report; RFS=recurrence-free survival; $\mathrm{DFS}=$ disease free survival; OS=0verall survival; $\mathrm{DSS}=$ disease specified survival; FoxP3 ${ }^{+}=$regulatory T-lymphocytes expressing forehead box P3 protein; Schalper 2015a collection termed YTMA79, Schalper 2015b collection termed YTMA140.

\section{$\mathrm{CD4}^{+} \mathrm{T}$ lymphocytes}

Six eligible studies provided estimates of HR and $95 \% \mathrm{CI}$ for the association between density of $\mathrm{CD}^{+} \mathrm{T}$ lymphocytes and survival. Figure $5 \mathrm{~A}$ indicated that a high level of $\mathrm{CD}^{+} \mathrm{T}$ lymphocytes was correlated with a good prognosis for overall survival $(\mathrm{HR}=0.78 ; 95 \% \mathrm{CI}$, $\left.0.66-0.93 ; P_{\mathrm{HR}}=0.005\right)$, but no significant difference was found for disease-specific survival $(\mathrm{HR}=0.64 ; 95 \% \mathrm{CI}$, $\left.0.24-1.74 ; P_{\mathrm{HR}}=0.386\right)$, and recurrence- or disease-free survival $\left(\mathrm{HR}=0.98 ; 95 \% \mathrm{CI}, 0.59-1.65, P_{\mathrm{HR}}=0.953\right)$.
We also carried out subgroup analyses to assess whether various clinical variables would affect overall survival (see Figure 5B). Exploratory subgroup analysis suggests that all patients benefit from high levels of $\mathrm{CD}^{+}$ T lymphocytes with respect to TIL location (stromal sites; $\mathrm{HR}=0.79 ; 95 \% \mathrm{CI}, 0.66-0.94)$, histology subtype (HR $=0.61 ; 95 \% \mathrm{CI}, 0.38-0.98$ for squamous cell carcinoma; and $\mathrm{HR}=0.81 ; 95 \% \mathrm{CI}, 0.67-0.98$ for NSCLCs), Asian patients ( $\mathrm{HR}=0.79 ; 95 \% \mathrm{CI}, 0.66-0.94)$, or percentage of positive lymph nodes $(<50 \%$; HR $=0.78 ; 95 \%$ CI, $0.66-$ 
A

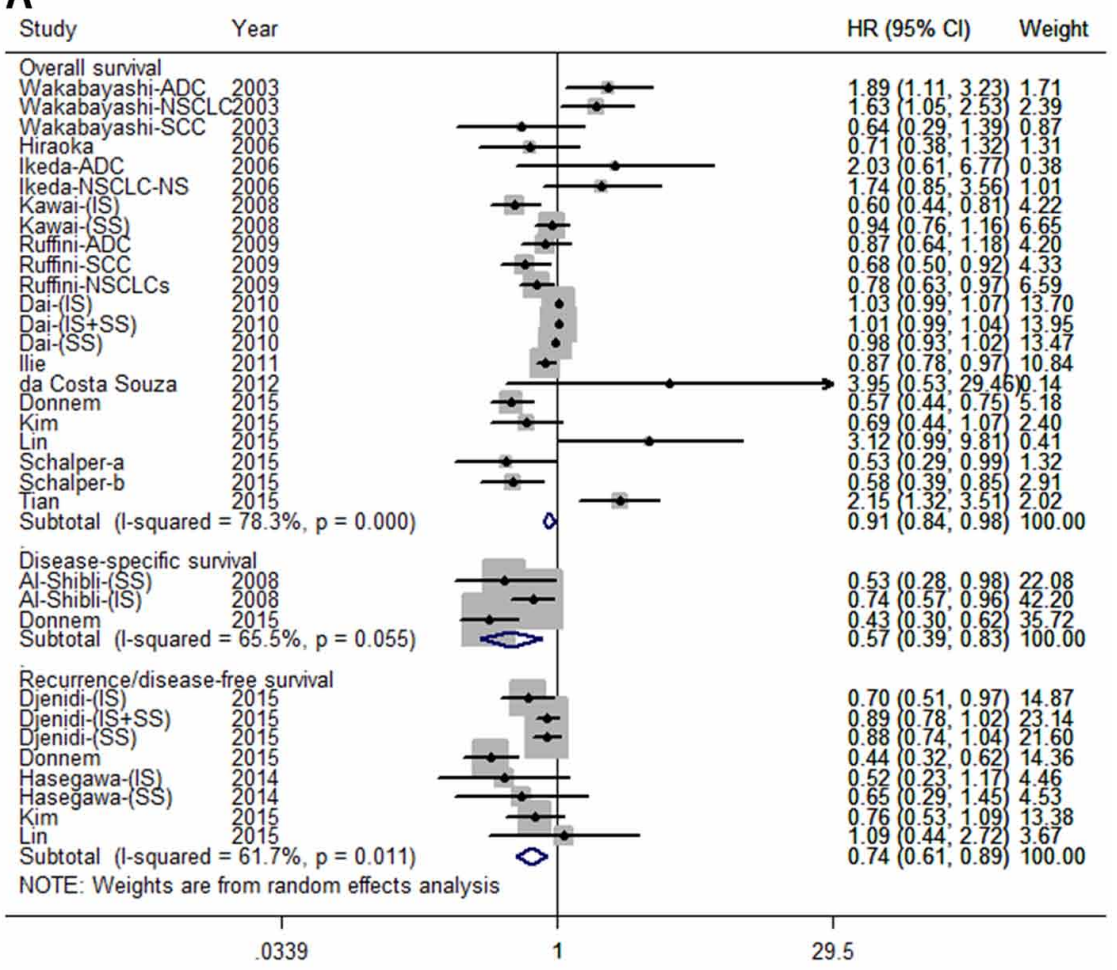

B

\begin{tabular}{|c|c|c|}
\hline Subgroups & $\mathrm{HR}(95 \% \mathrm{Cl})$ & $\mathrm{P}$ \\
\hline TILs location & & 0.131 \\
\hline IS & $0.92(0.78,1.08)$ & \\
\hline sS & $0.82(0.64,1.06)$ & \\
\hline IS+SS & $1.02(0.73,1.43)$ & \\
\hline Number of patients & & 0.000 \\
\hline$<200$ & $1.02(0.95,1.10)$ & \\
\hline$\geq 200$ & $0.73(0.64,0.84)$ & \\
\hline Histology subtype & & 0.003 \\
\hline$A D C$ & $1.57(0.84,2.93)$ & \\
\hline $\operatorname{scc}$ & $0.68(0.54,0.86)$ & \\
\hline NSCLCs & $0.92(0.85,0.99)$ & \\
\hline Region & & 0.000 \\
\hline Asia & $1.01(0.94,1.09)$ & \\
\hline Europe & $0.76(0.65,0.88)$ & \\
\hline America & $0.64(0.37,1.10)$ & \\
\hline Male & & 0.000 \\
\hline$<70 \%$ & $1.29(0.82,2.03)$ & \\
\hline$\geq 70 \%$ & $0.92(0.86,0.98)$ & \\
\hline NR & $0.58(0.44,0.76)$ & \\
\hline Positive lymph nodes & & 0.000 \\
\hline$<50 \%$ & $0.99(0.93,1.06)$ & \\
\hline$\geq 50 \%$ & $0.76(0.49,1.18)$ & \\
\hline NR & $0.72(0.52,1.00)$ & \\
\hline Overall & $0.91(0.84,0.98)$ & \\
\hline 1 & 293 & \\
\hline
\end{tabular}

Figure 2: Forest plots of studies on $\mathrm{CD8}^{+}$tumor-infiltrating lymphocytes. A. CD8 ${ }^{+}$tumor-infiltrating lymphocytes and survival in NSCLC. B. CD8 ${ }^{+}$tumor-infiltrating lymphocytes are associated with overall survival among cancer patients, according to various characteristics. Hazard ratios and $95 \%$ confidence intervals for survival are associated with high versus low $\mathrm{CD} 8{ }^{+}$counts; therefore a hazard ratio less than 1 represents a lower risk of death or progression associated with high $\mathrm{CD} 8^{+}$counts. ADC, adenocarcinoma; $\mathrm{CI}$, confidence interval; HR, hazard ratio; IS, intratumoral sites; NR, not reported; NSCLC, non-small cell lung cancer; SCC, squamous cell carcinoma; SS, stromal sites; TIL, tumor-infiltrating lymphocyte. 


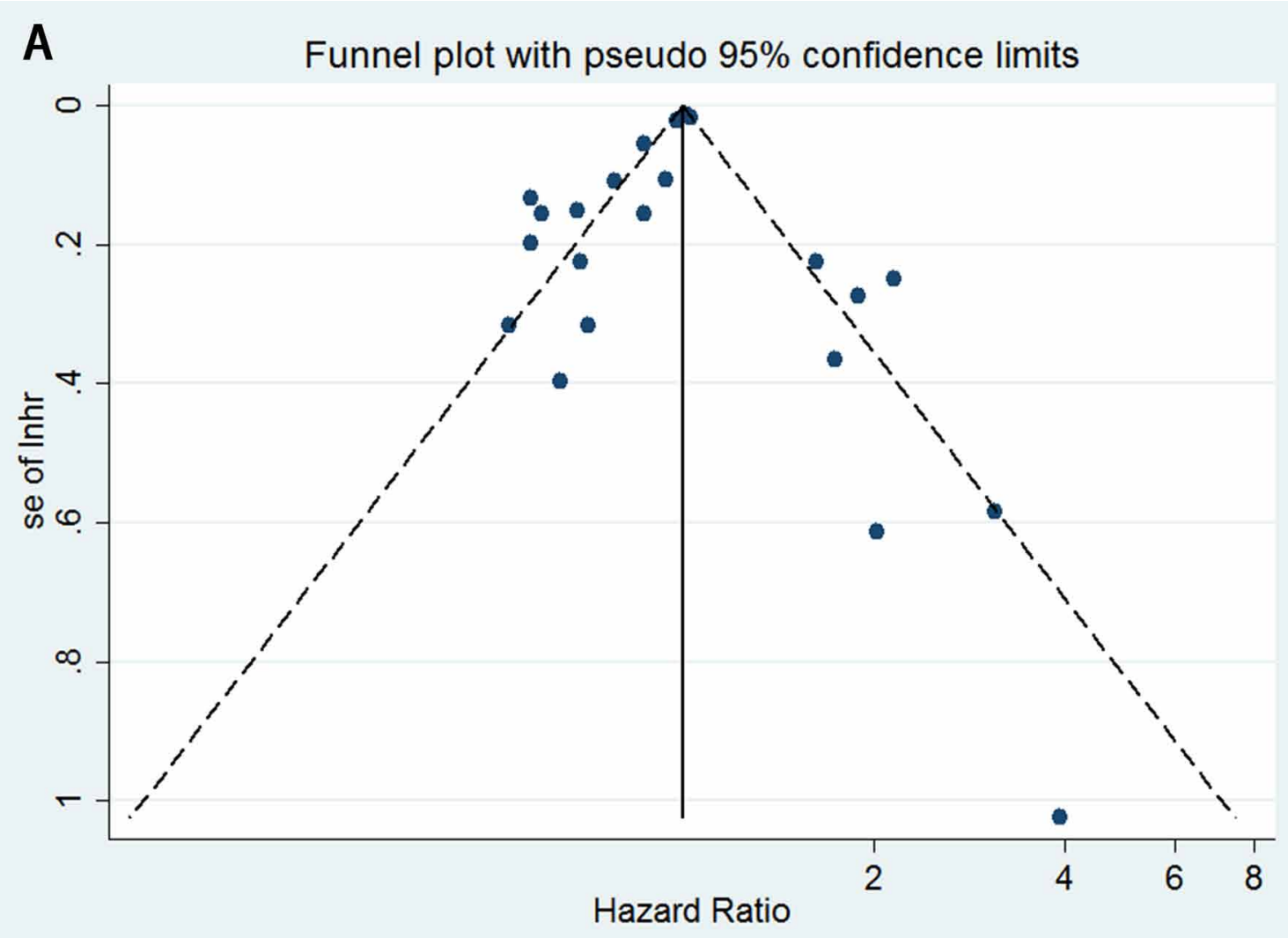

B

Funnel plot with pseudo $95 \%$ confidence limits

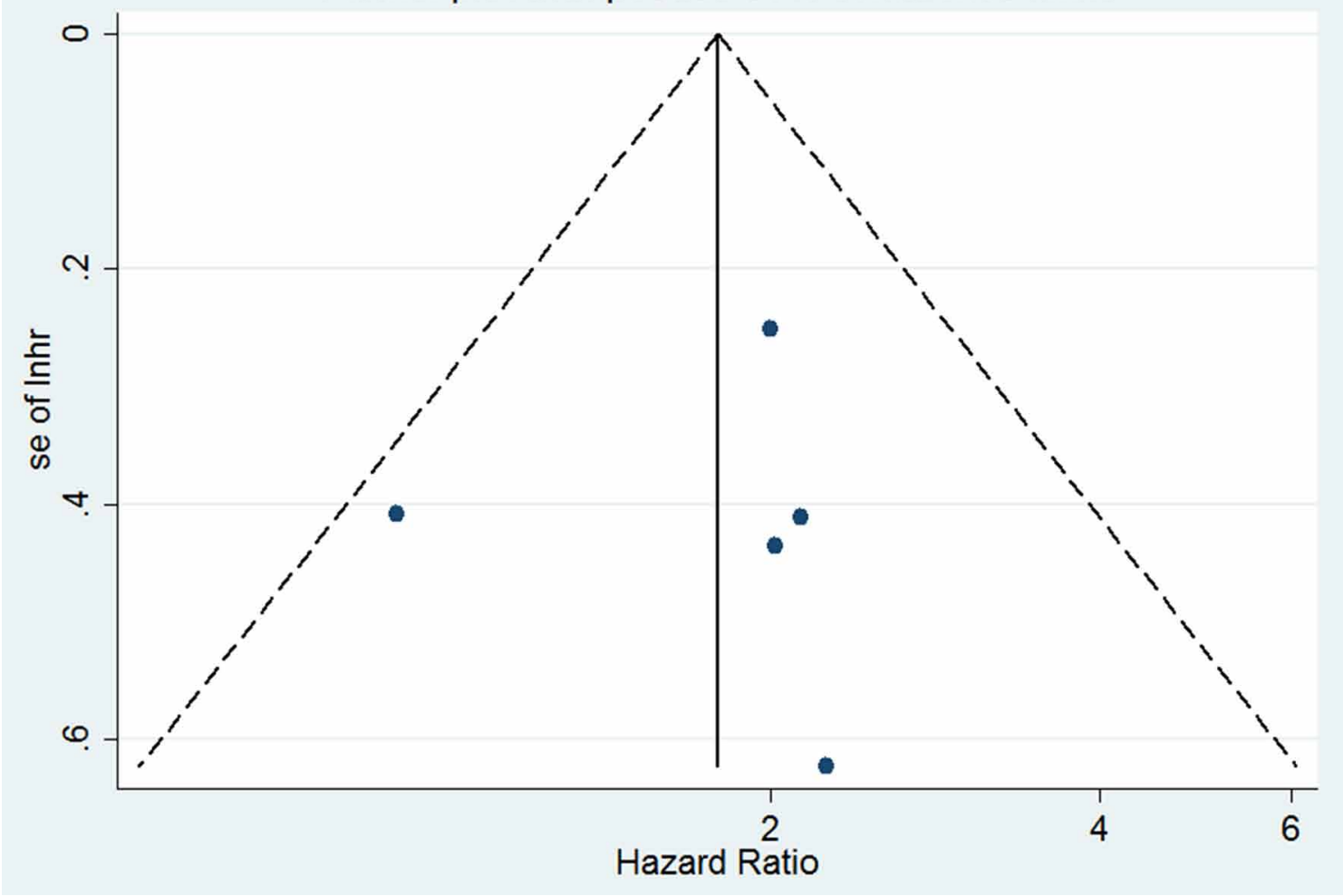

Figure 3: Funnel plots showing the associations between hazard ratios and standard error (se) for individual studies to assess publication bias. A. CD $8^{+}$tumor-infiltrating lymphocytes for overall survival. B. FoxP3 ${ }^{+}$tumor-infiltrating lymphocytes for recurrence-free survival. 


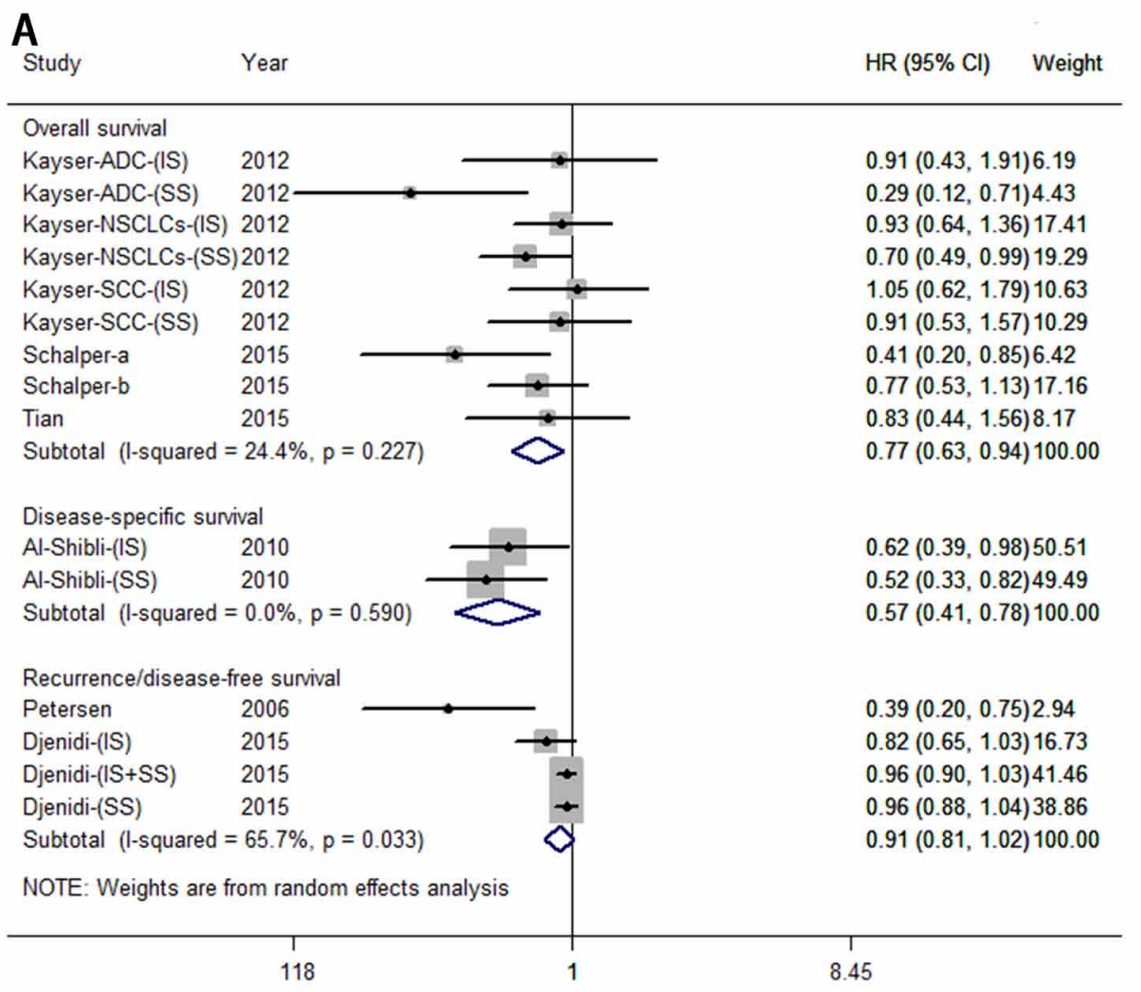

B

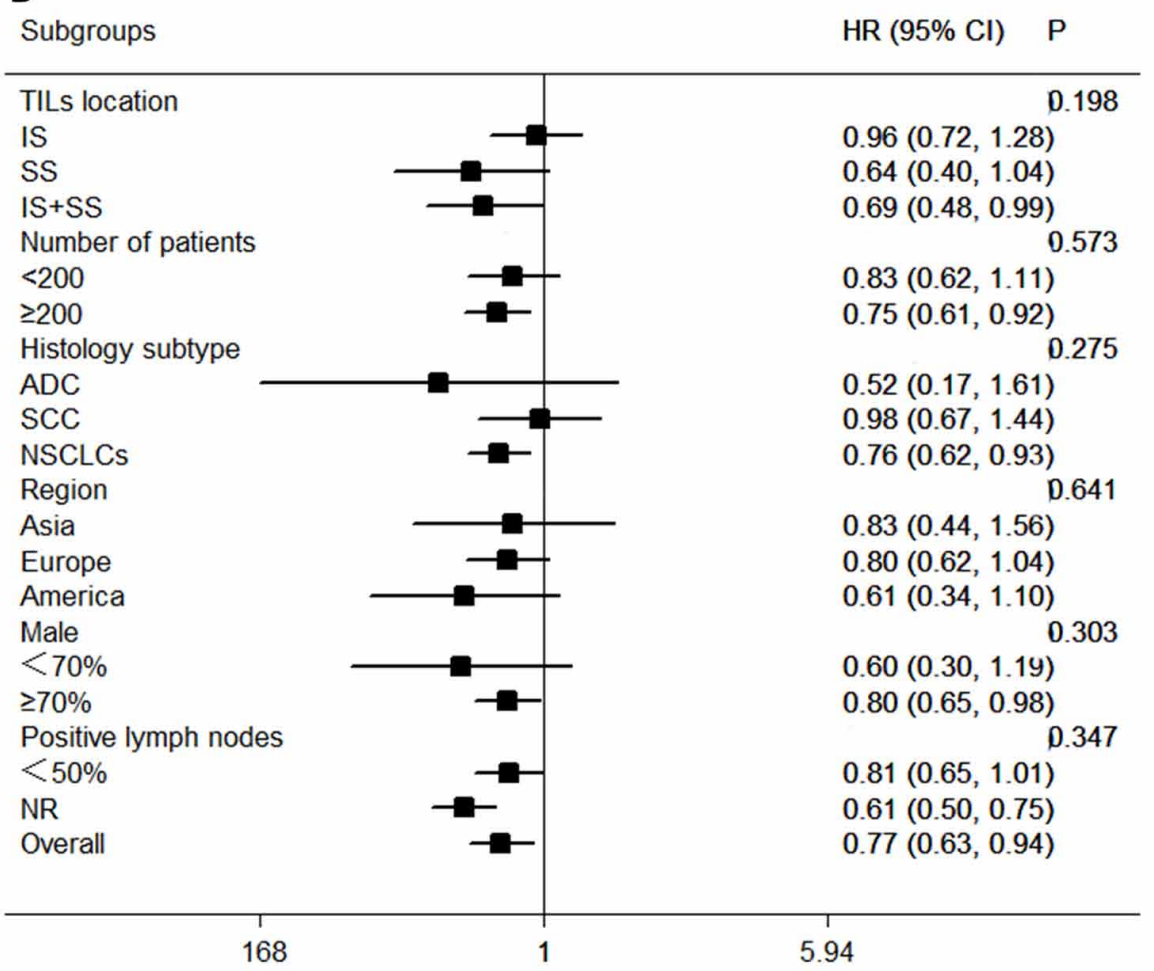

Figure 4: Forest plots of studies on $\mathrm{CD3}^{+}$tumor-infiltrating lymphocytes. A. CD3+ tumor-infiltrating lymphocytes and survival in NSCLC. B. CD3+ tumor-infiltrating lymphocytes are associated with overall survival among cancer patients according to various characteristics. Hazard ratios and $95 \%$ confidence intervals for survival are associated with high versus low $\mathrm{CD}^{+}$counts; therefore a hazard ratio less than 1 represents a lower risk of death or progression associated with high $\mathrm{CD}^{+}$counts. $\mathrm{ADC}$, adenocarcinoma; $\mathrm{CI}$, confidence interval; HR, hazard ratio; IS, intratumoral sites; NR, not reported; NSCLC, non-small cell lung cancer; SCC, squamous cell carcinoma; SS, stromal sites. TIL, tumor-infiltrating lymphocyte. 


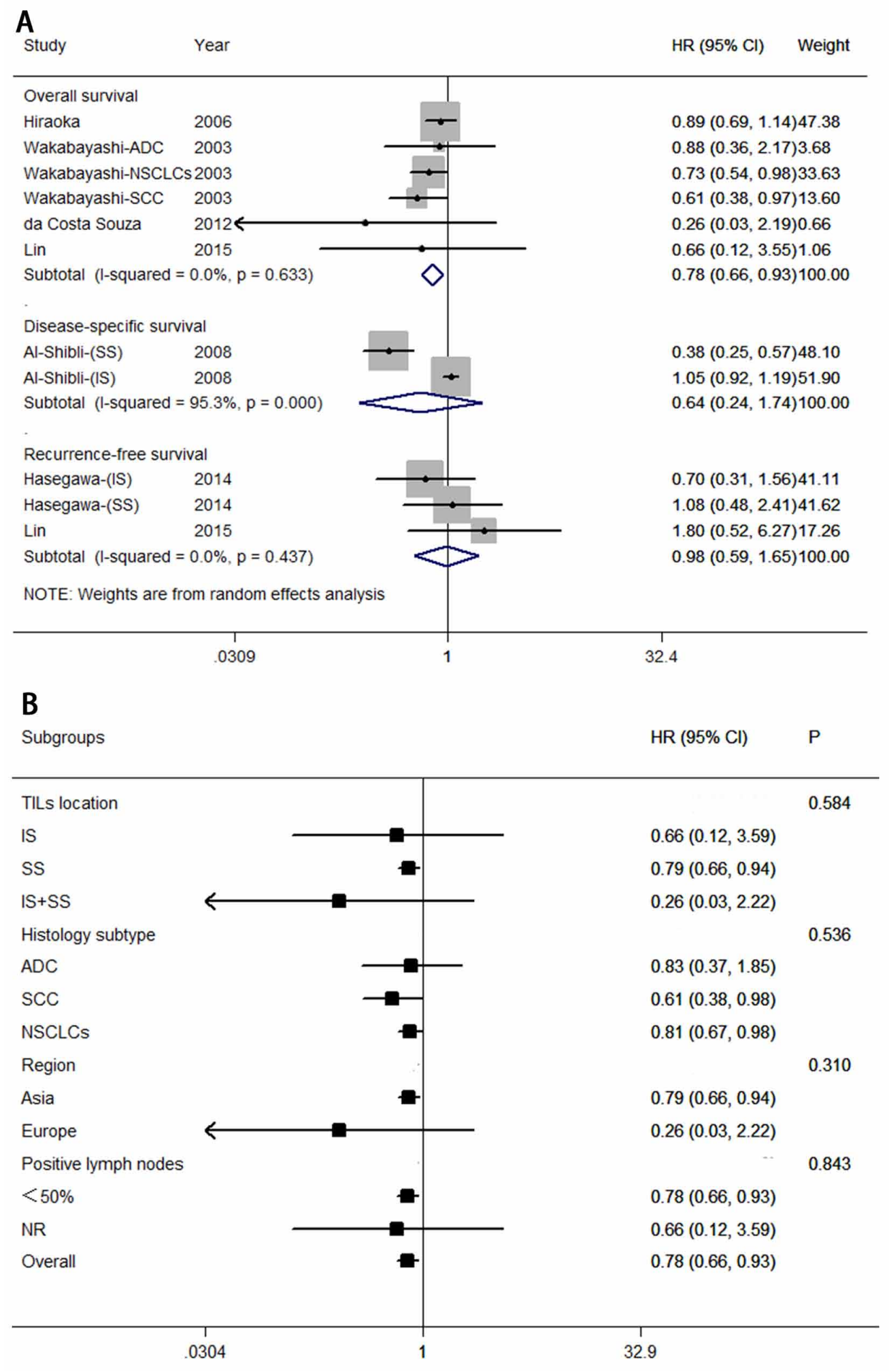

Figure 5: Forest plots of studies on CD4 ${ }^{+}$tumor-infiltrating lymphocytes. A. CD4+ tumor-infiltrating lymphocytes and survival in NSCLC. B. CD4 $4^{+}$tumor-infiltrating lymphocytes are associated with overall survival among cancer patients according to various characteristics. Hazard ratios and $95 \%$ confidence intervals for survival are associated with high versus low CD $4{ }^{+}$counts; therefore a hazard ratio less than 1 represents a lower risk of death or progression associated with high $\mathrm{CD}^{+}{ }^{+}$counts. ADC, adenocarcinoma; $\mathrm{CI}$, confidence interval; HR, hazard ratio; IS, intratumoral sites; NR, not reported; NSCLC, non-small cell lung cancer; SCC, squamous cell carcinoma; $\mathrm{SS}$, stromal sites. TIL, tumor-infiltrating lymphocyte. 
0.93). There was no evidence for a difference in treatment effect between any of the subgroups.

\section{FoxP3 $^{+}$Treg lymphocytes}

The value of $\mathrm{FoxP}^{+}$Treg lymphocytes for predictingsurvival was reported in six studies, involving 1,338 patients. Figure 6A indicated that low levels of FoxP3 ${ }^{+}$Treg lymphocytes correlated with a good prognosis for overall survival $(\mathrm{HR}=1.69 ; 95 \% \mathrm{CI}, 1.02$ $\left.2.81 ; P_{\mathrm{HR}}=0.042\right)$, and recurrence-free survival $(\mathrm{HR}=$ $1.79 ; 95 \%$ CI, 1.29-2.48; $\left.P_{\mathrm{HR}}=0.001\right)$. Egger's test $(P=$ $0.860)$ and Begg's test $(P=0.806)$, as well as a funnel plot (see Figure 3B), provided no evidence of publication bias for recurrence-free survival.

Subgroup analyses were also conducted to assess the potential correlation of various clinical variables with recurrence-free survival (see Figure 6B). Exploratory subgroup analysis suggested that all patients benefit from low levels of FoxP $3^{+}$Tre lymphocytes with respect to TIL location at both sites (intratumoral and stromal sites; HR $=2.08 ; 95 \% \mathrm{CI}, 1.16-3.73)$, number of patients $(\mathrm{HR}=$ $2.00 ; 95 \%$ CI, $1.22-3.27$ for $\geq 200$; and $\mathrm{HR}=1.63 ; 95 \%$ CI, 1.05-2.54 for <200), histology subtype ( $\mathrm{HR}=2.00$; 95\% CI, 1.22-3.27 for adenocarcinoma; and HR = 1.63; 95\% CI, 1.05-2.54 for NSCLCs), Asian patients (HR = 1.63 ; 95\% CI, 1.05-2.54), American patients $(\mathrm{HR}=2.00$; $95 \% \mathrm{CI}, 1.22-3.27)$, percentage of men $(<70 \%$; HR $=$ $1.73 ; 95 \%$ CI, 1.20-2.47), or percentage of positive lymph nodes $(<50 \%$; HR $=2.05 ; 95 \% \mathrm{CI}, 1.43-2.94)$. There was no evidence of a difference in treatment effects between any of the subgroups.

\section{Ratios between $\mathrm{T}$ lymphocyte subsets}

Relatively few studies evaluated the prognostic impact of TIL ratio subsets on survival. Thus, we only investigated the associations between survival and $\mathrm{CD}^{+} /$ $\mathrm{CD}^{+}$ratio, and between survival and $\mathrm{FoxP}^{+} / \mathrm{CD}^{+}$ ratio. All studies concerned with ratios were pooled in a forest plot (Figure 7). Surprisingly, pooled results for three studies reporting recurrence-free survival based on $\mathrm{FoxP}^{+} / \mathrm{CD}^{+}$ratio were strongly significant $(\mathrm{HR}=1.89$; $95 \%$ CI, $\left.1.27-2.80 ; P_{\mathrm{HR}}=0.002 ; I^{2}=48 \%\right)$, indicating that a high $\mathrm{FoxP}^{+} / \mathrm{CD}^{+}$ratio is a risk factor for recurrence. Three studies observed that high $\mathrm{CD} 4^{+} / \mathrm{CD}^{+}$ratio coexpression are favorable compared with low numbers of both cell types for overall survival $(\mathrm{HR}=0.31 ; 95 \%$ CI, 0.13-0.75; $\left.P_{\mathrm{HR}}=0.009\right)$ and disease-specific survival $\left(\mathrm{HR}=0.13 ; 95 \% \mathrm{CI}, 0.03-0.57 ; P_{\mathrm{HR}}=0.007\right)$; however, a moderate to high heterogeneity was noted for diseasespecific survival $\left(I^{2}=65.1 \%, P=0.146\right)$.

\section{DISCUSSION}

In this meta-analysis, which included data of a cohort of 7,006 patients identified as having NSCLC from 24 studies, we provided quantitative estimates of the prognostic value of TILs in patients with NSCLC. We have demonstrated that comparing high and low densities of $\mathrm{CD}^{+}, \mathrm{CD}^{+}$, or $\mathrm{CD}^{+}$TILs alone in patients with NSCLC indicated that high densities of these subtypes of TILs alone could be a relatively pronounced predictive marker, with better associated outcomes than low infiltrate densities in terms of overall survival. Similarly high levels of $\mathrm{CD}^{+}$or $\mathrm{CD}^{+}$lymphocytes, or high $\mathrm{CD}^{+} / \mathrm{CD}^{+}$ratios, were strongly independent prognostic biomarkers for disease-specific survival, but were used in relatively few studies. By contrast, low levels of FoxP $3^{+}$regulatory TILs or low $\mathrm{FoxP}^{+} / \mathrm{CD}^{+}$ratio were found to correlate with a good prognosis for overall or recurrence-free survival. Data on NSCLCs were somewhat limited; thus, the analysis failed to demonstrate a disease-specific survival prognostic value for FoxP3 ${ }^{+}$regulatory TILs.

Since tumor-infiltrating immune cells have been shown to have prognostic value for several solid malignancies, immunotherapy has attracted much research interest. Historically, a number of researches have advocated, through their work in cancer, the use of three important parameters of TILs - subtype, density, and location-to predict clinical outcomes [7, 39, 40]. This is somewhat consistent with another study evaluating $\mathrm{CD}^{+}$ and $\mathrm{CD}^{+}$cells by chromogenic immunohistochemistry in patients with NSCLC. The authors of this study [16, 19] found an association between high levels of $\mathrm{CD}^{+} \mathrm{T}$ cells in cancer stroma and longer survival. However, these results were obtained from relatively small collections of samples from single institutions and without validation in an independent set. In our meta-analysis, data on patients with NSCLC were analyzed to assess the potential contributions of various clinical variables to survival outcomes. We investigated four markers of TILs and found that high levels of $\mathrm{CD}^{+}$lymphocytes in tumorassociated stroma to be significantly associated with survival. There is compelling evidence that this is due to the immunosuppressive effects of $\mathrm{CD}^{+} \mathrm{T}$ cells, which play a central role in orchestrating the immune response to lung cancer [41]. Interestingly, $\mathrm{CD}^{+}$lymphocytes in the stroma only, and not in intratumoral sites, were associated with death, emphasizing the importance of assessing the location of TILs within the tumor microenvironment. In fact, the significance of immune cells in the tumor stroma has been shown in NSCLC.

It is well known that patients with different subtypes of NSCLC have different responses, and we demonstrate that in addition to TILs, subtype, density, and location, a fourth characteristic of TILs-NSCLC subtype-is an important parameter. Stratified analysesrevealed that the survival of patients with squamous cell carcinoma has a positive association with high density of $\mathrm{CD}^{+}$or $\mathrm{CD}^{+}$TILs alone. Additionally, our analysis showed that high levels of FoxP $3^{+}$regulatory $\mathrm{T}$ cells are thought to play protumor roles, and their significant association with greater rates of recurrence has been shown for 


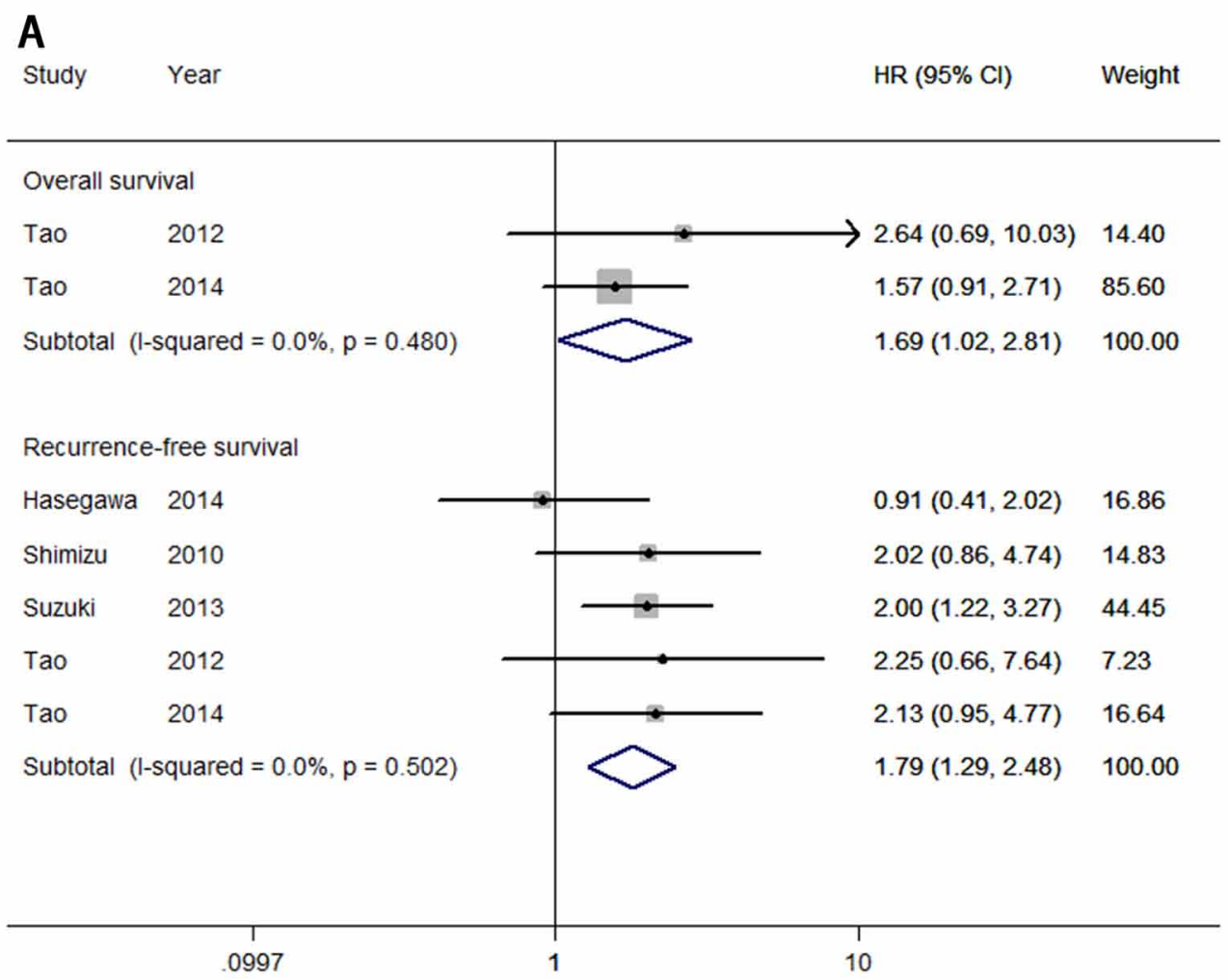

B

\begin{tabular}{|c|c|c|}
\hline Subgroups & $\mathrm{HR}(95 \% \mathrm{Cl})$ & $\mathrm{P}$ \\
\hline TILs location & & 0.543 \\
\hline SS & $1.60(0.93,2.75)$ & \\
\hline IS+SS & $2.08(1.16,3.73)$ & \\
\hline No. of Patient & & 0.548 \\
\hline$<200$ & $1.63(1.05,2.54)$ & \\
\hline$\geq 200$ & $2.00(1.22,3.27)$ & \\
\hline Histology subtype & & 0.548 \\
\hline ADC & $2.00(1.22,3.27)$ & \\
\hline NSCLCs & $1.63(1.05,2.54)$ & \\
\hline Region & & 0.548 \\
\hline Asia & $1.63(1.05,2.53)$ & \\
\hline America & $2.00(1.22,3.27)$ & \\
\hline Male & & 0.640 \\
\hline$<70 \%$ & $1.73(1.21,2.48)$ & \\
\hline$\geq 70 \%$ & $2.13(0.95,4.77)$ & \\
\hline Positive lymph nodes & & 0.069 \\
\hline$<50 \%$ & $2.05(1.43,2.94)$ & \\
\hline$\geq 50 \%$ & $0.91(0.41,2.02)$ & \\
\hline Overall & $1.79(1.29,2.48)$ & \\
\hline $\begin{array}{c}1 \\
21\end{array}$ & & \\
\hline
\end{tabular}

Figure 6: Forest plots of studies on FoxP3 ${ }^{+}$TILs. A. FoxP3 ${ }^{+}$tumor-infiltrating lymphocytes and survival in NSCLC. B. FoxP3 ${ }^{+}$ tumor-infiltrating lymphocytes are associated with recurrence-free survival among cancer patients according to various characteristics. Hazard ratios and $95 \%$ confidence intervals for survival are associated with high versus low FoxP3 ${ }^{+}$counts; therefore a hazard ratio less than 1 represents a lower risk of death or progression associated with high FoxP3 ${ }^{+}$counts. ADC, adenocarcinoma; CI, confidence interval; HR, hazard ratio; IS, intratumoral sites; NSCLC, non-small cell lung cancer; SS, stromal sites. TIL, tumor-infiltrating lymphocyte. 


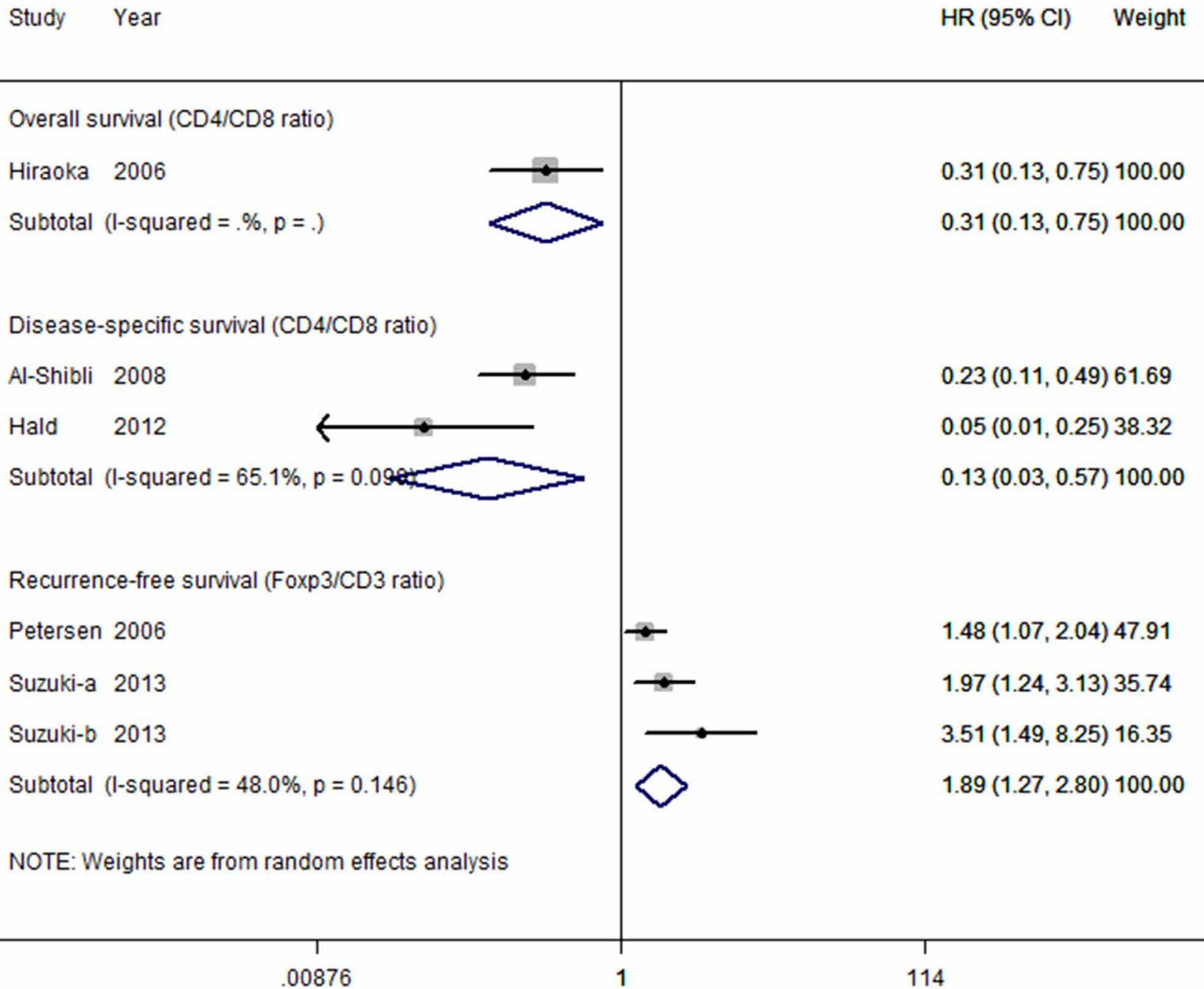

Figure 7: Forest plot of tumor-infiltrating lymphocyte ratios and survival in NSCLC. Hazard ratios and 95\% confidence intervals for survival are associated with high versus low tumor-infiltrating lymphocyte ratio counts; therefore a hazard ratio less than 1 represents a lower risk of death or progression associated with high tumor-infiltrating lymphocyte ratio counts. CI, confidence interval; HR, hazard ratio.

adenocarcinoma. Fox $3^{+}$is a marker of regulatory T cells, a subset of TILs thought to play a major role in hampering antitumor immune response, and to represent a major cellular mechanism underlying immune evasion of lung cancer [41]. In patients with lung cancer, regulatory T cells are thought to play protumor roles and their association with worse prognosis has been demonstrated for all histologic types [42]. In addition to revealing prognostic value, this finding has significant implications for devising potential immunomodulatory therapy for patients with lung adenocarcinoma and squamous cell carcinoma; an intervention that decreases levels of $\mathrm{FoxP}^{+}$and increases levels of $\mathrm{CD}^{+}{ }^{+}$or $\mathrm{CD} 8^{+}$TILs would likely to be beneficial. Furthermore, more well-designed clinical trials are needed to confirm the clinical prognostic utilization of TIL subtypes in patients with different subtypes of NSCLC.

In addition to the presence of different subsets of TILs, ratios some of these types of subset were also reported in previous clinical studies. We investigated the associations between NSCLC survival and $\mathrm{CD}^{+} /$ $\mathrm{CD}^{+}$ratio and between NSCLC survival $\mathrm{FoxP}^{+} /$ $\mathrm{CD}^{+}$ratio. Our analysis clearly demonstrated that a good response $\mathrm{FoxP}_{3} / \mathrm{CD}^{+}$ratio was a risk factor for disease recurrence, while a good response $\mathrm{CD}^{+} /$ $\mathrm{CD}^{+}$ratio is favorable for survival, compared with low numbers of both cell types for overall and diseasespecific survival. Additionally, a survival analysis by Kayser et al. [30] showed that high numbers of stromal $\mathrm{CD} 4^{+} / \mathrm{CD} 25^{+} \mathrm{T}$ lymphocytes are of beneficial prognostic influence in patients with NSCLC, especially with adenocarcinomas. Previous experiments demonstrated that $\mathrm{CD}^{+} / \mathrm{CD} 25^{+} \mathrm{T}$ lymphocytes have a regulatory function on tumor-reactive cytotoxic $\mathrm{T}$ lymphocytes and thereby successfully suppress lymphocytic tumor rejection [41, 43]. Ilie et al. [29] reported on the relationship between ratio of $\mathrm{CD} 66 \mathrm{~b}^{+} / \mathrm{CD} 8^{+}$TILs and 
survival. This study demonstrated that a high $\mathrm{CD} 66 \mathrm{~b}^{+} /$ $\mathrm{CD}^{+}$ratio is an independent prognostic factor for a high rate of disease recurrence and death in patients with NSCLC. Considering the limited number of studies that reported the relationship between survival and ratios or changes in subtypes of TILs, more prospective studies are needed.

Beside the potential prognostication for NSCLC, we observed that TILs are a potential predictive biomarker for therapy. Liu et al. proved that the ratio of $\mathrm{CD}^{+} / \mathrm{FoxP}^{+}$TILs independently predicted a good response to platinum-based chemotherapy for patients with advanced NSCLC [11]. Kawai et al. [23] reported that higher $\mathrm{CD}^{+}$infiltration within the tumor nest after platinum-based chemotherapy was strongly associated with better overall survival in patients with stage IV NSCLC. Tao et al. [34] demonstrated that a low density of FoxP ${ }^{+}$TILs indicated a better response to induction chemoradiation and better survival in locally advanced NSCLC, although the difference was not statistically significant, suggesting that FoxP3 ${ }^{+}$TILs might be a target for adjunct immunotherapy. Furthermore, cytotoxic $\mathrm{CD}^{+} \mathrm{T}$ cells are crucial in novel therapies targeting the immune system, e.g., by blocking CD8 T cell-related ligands (PD-L1 and PD-L2) and receptors (PD-1 and CTLA-4), antitumor immunity is enhanced in patients with various types of advanced solid tumors, including NSCLC [44]. These findings on TILs provided comprehensive information and a rationale for PD-1/PD-L1 pathway-targeted immunotherapy and other promising immunotherapy for patients with NSCLC. Based on these studies, the accumulation of $\mathrm{CD}^{+}$TILs and depletion of FoxP $3^{+}$TILs are thought to be favorable prognostic factors in patients with NSCLC, and these findings support the idea that augmentation of the local immune response might be a promising target for new immunotherapeutic approaches [45]. However, owing to insufficient data on the associations between levels of TILs and prognostic responses after systemic therapy, we did not find a statistically favorable survival outcome in pooled analyses. We believed that TILs could be monitored as a potential predictor for future therapies to treat NSCLC. High-quality randomized studies are needed to verify, statistically, the effect of TILs on prognosis in future NSCLC clinical therapeutic research.

The major strength of this study is that we have searched all published studies via electronic and hand searching that met the inclusion criteria and that no single study affected the results, and no publication bias was found in the survival panels, indicating that our main findings are robust. To the best of our knowledge, this meta-analysis is the first comprehensive assessment of the prognostic value of TILs for NSCLC, which may be useful for future research. Moreover, we conducted a stratified analysis for overall results based on location of
TILs, number of participations, histology subtype, region, percentage of men, and percentage of positive lymph nodes, which could improve the reliability of the results and reduce the performance bias of the meta-analysis. Furthermore, the included studies, which were published between 2003 and 2015, provide accumulating evidence and a large sample size, which significantly increased the statistical power of the analysis to provide precise and reliable risk estimates. In addition, we dutifully preformed a broad search strategy for articles that considered the most frequently used T lymphocyte markers for NSCLC survival prognostication. Finally, the inclusion of studies from different countries suggests that the clinical utilization of TIL subtypes in patients with NSCLC is a global concern, with lung cancer accounting for more than one-quarter (27\%) of all cancer deaths [46].

Despite these advantages, several limitations might be acknowledged in this meta-analysis. First, there is no international unification measurement to determine levels of TILs, and TIL location is also not assessed in a standardized manner; this increased the difficulty in performing the meta-analysis. Subsets of TILs from different locations, as well as subtypes of NSCLC should be investigated in future studies.

Second, all of the included studies were retrospective in design, with insufficient data, such as therapy details, tumor stage, cut-off point, smoking history, patient age, or molecular tumor alterations (e.g., epidermal growth factor receptor (EGFR), Kirsten rat sarcoma viral oncogene, or anaplastic lymphoma kinase), and thus the results could not be further stratified with other potential confounding factors that can affect the major outcomes. Moreover, further research on associations between TILs and clinicopathologic characteristics (e.g., PD-1 expression, PD-L1 expression), and more high-quality continuous treatment trials with TILs that might improve survival of NSCLC using immune-targeted chemotherapy or molecular targeted therapy, are needed to conform these results.

Third, in several studies, HRs for outcome measures were derived from Kaplan-Meier survival curves when not provided by the original studies directly; these would affect the level of evidence. Therefore, the facticity of the results might be influenced by this. Finally, further studies with better confounding factor adjustments are needed because data in the original publications could not be obtained, which might affect the risk estimates.

In conclusion, despite these limitations, we have demonstrated that TILs might serve as a robust marker for prognosticating the survival of patients with NSCLC, especially in TIL subtypes $\mathrm{CD}^{+}, \mathrm{CD}^{+}, \mathrm{CD}^{+}$, and $\mathrm{FoxP}^{+}$. Future well-designed clinical trials, especially randomized controlled trials, are required to confirm current findings and statistically verify the effect of TILs on prognosis in future clinical therapeutic research on NSCLC. 


\section{MATERIALS AND METHODS}

\section{Literature search}

We followed the PRISMA guidelines (preferred reporting items for systematic reviews and meta-analyses statement) for this meta-analysis [47]. The PubMed, ISI Web of Science, EMBASE and Cochrane Library databases (updated to March 2015) were searched to identify relevant studies that investigated the predictive clinical outcome of TILs in NSCLC. The following terms were used: "Lymphocytes, Tumor-Infiltrating," "T Lymphocytes," "FoxP3-positive T lymphocytes," "CD8Positive T Lymphocytes," "CD3-Positive T Lymphocytes," "CD4-Positive T Lymphocytes," "T lymphocytes," "non-small cell lung cancer," "Lung Adenocarcinoma," and "Lung Squamous cell carcinoma." No restriction was imposed on the search in terms of sample size, population, time period, language, or type of report. All eligible studies were retrieved, and the reference lists of the reviews or studies identified in the literature search were hand-searched for additional information when key information was missing.

\section{Inclusion criteria}

Studies were included according to the following criteria: (1) the studies investigated the predictive clinical outcome of TILs (including $\mathrm{CD}^{+}, \mathrm{CD} 4^{+}, \mathrm{CD} 8^{+}$, and FoxP $3^{+}$lymphocytes, and including ratios between these subsets) as a prognostic and predictive marker in patients with NSCLC, as identified by hematoxylin \& eosin or immunohistochemistry staining, and which analyzed lymphocytes in intratumoral or stromal sites; (2) the studies were published as original full-text articles; (3) the studies reported prognostic information, including HRs for the relationship between TILs and tumor response outcome measures, including overall survival, recurrence- or diseasefree survival, and disease-specific survival, or reported adequate data for the HRs to be computed. If duplicate data were presented in several studies, only the most recent and largest or most complete study was included.

\section{Data extraction and outcome measure}

The information from the studies was independently extracted by two researchers (DongQiang Zeng and Yun-Fang Yu) according to the inclusion criteria, and the data were checked by other investigators. Data were abstracted as follows: first author, year of publication, ethnicity, number of patients, percentage of men, tumor stage, histologic subtype, percentage of positive lymph nodes, TIL subsets, TIL locations, definition of high levels of TILs, and outcomes of univariate or multivariate analysis reported. However, as all of the included articles were retrospective, the quality of each study was not assessed.
The outcomes from univariate or multivariate Cox regression, that is, HRs and $95 \% \mathrm{CIs}$, were used for analysis. If both univariate and multivariate analysis for the same comparison were reported in studies, we only used the latter. When Kaplan-Meier curves were provided rather than the HRs, the HRs were calculated indirectly from the curves using the procedure proposed by Tierney et al. [48], which is based on the method reported by Parmar et al. [49]. The data which were collected were in accordance with the quality of meta-analyses statement. Since studies used different definitions for high and low levels of TILs, we considered the ratio of results between tumors with high levels of TIL expression versus those with low levels of or no TIL expression for each TIL subset. The reciprocals of HRs and CIs were taken to calculate the results the other way around, for studies that reported HRs for low versus high levels of TILs. To ensure the accuracy of the extracted information, other investigators who judged the inclusion and exclusion of the studies were blinded to the identity information of the studies. Disagreements on eligibility were resolved through discussion and consensus with other authors.

\section{Statistical analyses}

For time-to-event data, we pooled estimated HRs, together with associated 95\% CIs from the original articles. For overall results, $P<0.05$ was considered statistically significant. $I^{2}$ statistics [50] were applied to measure the heterogeneity of the studies and to provide a quantitative measure of inconsistency among studies. A random-effects model, the DerSimonian and Laird method [51], was utilized when $I^{2}>50 \%$ or $P<0.1$; otherwise, a fixed-effect model, the Mantel-Haenszel method [52], was applied. When heterogeneity was observed, either subgroup or sensitivity analysis was performed, to assess the potential contributions of various clinical variables to the main outcome, while sensitivity analysis was performed by sequentially excluding studies in turn, to test the stability of the main results. Additionally, since we wondered whether study characteristics would affect study outcomes, subgroup analyses were carried out for the overall results. The potential publication bias was evaluated through visual inspection of a contour-enhanced funnel plot [53], Begg's test [54] and Egger's [55] unweighted regression tests. $P<0.05$ indicates publication bias, and $P>0.05$ indicates no bias. All tests were two-sided. Statistical analyses were calculated using STATA version 12. 1 (STATA Corporation, College Station, TX, USA). To ensure the reliability and accuracy of the results, two authors independently uploaded the data.

\section{ACKNOWLEDGMENTS}

We thank LetPub (www.letpub.com) for linguistic assistance during the preparation of this manuscript. 


\section{CONFLICTS OF INTEREST}

There are no conflicts of interest to declare.

\section{Author contributions}

Dong-Qiang Zeng and Yun-Fang Yu and Qi-Yun Ou: contributed to the literature search, study design, analysis and collection of the data, and drafting of the manuscript. Xiao-Yin Li and Ru-Zhi Zhong: contributed to the analysis and collection of the data, and drafting of the manuscript. Qiu-Gen Hu and Chuan-Miao Xie: contributed to the study design, analysis and collection of the data, and review of manuscript.

\section{REFERENCES}

1. Fridman WH, Pages F, Sautes-Fridman C and Galon J. The immune contexture in human tumours: impact on clinical outcome. Nature reviews Cancer. 2012; 12:298-306.

2. Pardoll DM. The blockade of immune checkpoints in cancer immunotherapy. Nature reviews Cancer. 2012; 12:252-264.

3. Apetoh L, Ghiringhelli F, Tesniere A, Obeid M, Ortiz C, Criollo A, Mignot G, Maiuri MC, Ullrich E, Saulnier P, Yang H, Amigorena S, Ryffel B, Barrat FJ, Saftig P, Levi F, et al. Toll-like receptor 4-dependent contribution of the immune system to anticancer chemotherapy and radiotherapy. Nature medicine. 2007; 13:1050-1059.

4. Zitvogel L, Kepp O and Kroemer G. Immune parameters affecting the efficacy of chemotherapeutic regimens. Nature reviews Clinical oncology. 2011; 8:151-160.

5. Pages F, Berger A, Camus M, Sanchez-Cabo F, Costes A, Molidor R, Mlecnik B, Kirilovsky A, Nilsson M, Damotte D, Meatchi T, Bruneval P, Cugnenc PH, Trajanoski Z, Fridman WH and Galon J. Effector memory $\mathrm{T}$ cells, early metastasis, and survival in colorectal cancer. The New England journal of medicine. 2005; 353:2654-2666.

6. Pages F, Kirilovsky A, Mlecnik B, Asslaber M, Tosolini M, Bindea G, Lagorce C, Wind P, Marliot F, Bruneval P, Zatloukal K, Trajanoski Z, Berger A, Fridman WH and Galon J. In situ cytotoxic and memory $\mathrm{T}$ cells predict outcome in patients with early-stage colorectal cancer. Journal of clinical oncology. 2009; 27:5944-5951.

7. Galon J, Costes A, Sanchez-Cabo F, Kirilovsky A, Mlecnik B, Lagorce-Pages C, Tosolini M, Camus M, Berger A, Wind $\mathrm{P}$, Zinzindohoue $\mathrm{F}$, Bruneval $\mathrm{P}$, Cugnenc $\mathrm{PH}$, Trajanoski Z, Fridman WH and Pages F. Type, density, and location of immune cells within human colorectal tumors predict clinical outcome. Science (New York, NY). 2006; 313:1960-1964.

8. Pages F, Galon J, Dieu-Nosjean MC, Tartour E, SautesFridman $\mathrm{C}$ and Fridman WH. Immune infiltration in human tumors: a prognostic factor that should not be ignored. Oncogene. 2010; 29:1093-1102.
9. Adams S, Gray RJ, Demaria S, Goldstein L, Perez EA, Shulman LN, Martino S, Wang M, Jones VE, Saphner TJ, Wolff AC, Wood WC, Davidson NE, Sledge GW, Sparano JA and Badve SS. Prognostic value of tumor-infiltrating lymphocytes in triple-negative breast cancers from two phase III randomized adjuvant breast cancer trials: ECOG 2197 and ECOG 1199. Journal of clinical oncology. 2014; 32:2959-2966.

10. Halama N, Michel S, Kloor M, Zoernig I, Benner A, Spille A, Pommerencke T, von Knebel DM, Folprecht G, Luber B, Feyen N, Martens UM, Beckhove P, Gnjatic S, Schirmacher $\mathrm{P}$, Herpel E, et al. Localization and density of immune cells in the invasive margin of human colorectal cancer liver metastases are prognostic for response to chemotherapy. Cancer research. 2011; 71:5670-5677.

11. Liu H, Zhang T, Ye J, Li H, Huang J, Li X, Wu B, Huang X and Hou J. Tumor-infiltrating lymphocytes predict response to chemotherapy in patients with advance non-small cell lung cancer. Cancer immunology, immunotherapy. 2012; 61:1849-1856.

12. Detterbeck FC, Postmus PE and Tanoue LT. The stage classification of lung cancer: Diagnosis and management of lung cancer, 3rd ed: American College of Chest Physicians evidence-based clinical practice guidelines. Chest. 2013; 143:e191S-210S.

13. Suzuki K, Kadota K, Sima CS, Nitadori J, Rusch VW, Travis WD, Sadelain M and Adusumilli PS. Clinical impact of immune microenvironment in stage I lung adenocarcinoma: tumor interleukin-12 receptor beta2 (IL-12Rbeta2), IL-7R, and stromal FoxP3/CD3 ratio are independent predictors of recurrence. Journal of clinical oncology. 2013; 31:490-498.

14. Lin C, Chen X, Li M, Liu J, Qi X, Yang W, Zhang H, Cai Z, Dai Y and Ouyang X. Programmed Death-Ligand 1 Expression Predicts Tyrosine Kinase Inhibitor Response and Better Prognosis in a Cohort of Patients With Epidermal Growth Factor Receptor Mutation-Positive Lung Adenocarcinoma. Clinical lung cancer. 2015.

15. Kim MY, Koh J, Kim S, Go H, Jeon YK and Chung DH. Clinicopathological analysis of PD-L1 and PD-L2 expression in pulmonary squamous cell carcinoma: Comparison with tumor-infiltrating $\mathrm{T}$ cells and the status of oncogenic drivers. Lung Cancer. 2015; 88:24-33.

16. Hiraoka K, Miyamoto M, Cho Y, Suzuoki M, Oshikiri T, Nakakubo Y, Itoh T, Ohbuchi T, Kondo S and Katoh H. Concurrent infiltration by CD8 $+\mathrm{T}$ cells and CD4 $+\mathrm{T}$ cells is a favourable prognostic factor in non-small-cell lung carcinoma. British Journal of Cancer. 2006; 94:275-280.

17. Kikuchi E, Yamazaki K, Torigoe T, Cho Y, Miyamoto M, Oizumi S, Hommura F, Dosaka-Akita H and Nishimura M. HLA class I antigen expression is associated with a favorable prognosis in early stage non-small cell lung cancer. Cancer Sci. 2007; 98:1424-30.

18. Kawai O, Ishii G, Kubota K, Murata Y, Naito Y, Mizuno T, Aokage K, Saijo N, Nishiwaki Y, Gemma A, Kudoh S 
and Ochiai A. Predominant infiltration of macrophages and CD8 (+) T Cells in cancer nests is a significant predictor of survival in stage IV non-small cell lung cancer. Cancer. 2008;113:1387-95.

19. Wakabayashi O, Yamazaki K, Oizumi S, Hommura F, Kinoshita I, Ogura S, Dosaka-Akita H and Nishimura M. CD4+ T cells in cancer stroma, not CD8+ T cells in cancer cell nests, are associated with favorable prognosis in human non-small cell lung cancers. Cancer Science. 2003; 94:1003-1009.

20. Ikeda S, Funakoshi N, Inagaki $M$ and Shibata $T$. Clinicopathologic roles of tumor-infiltrating lymphocytes and CD8-positive lymphocytes in lung cancer imprint smears in squamous cell carcinoma and adenocarcinoma Acta Cytologica. 2006; 50:423-429.

21. Petersen RP, Carnpa MJ, Sperlazza J, Conlon D, Joshi M-B, Harpole DH, Jr. and Patz EF, Jr. Tumor infiltrating FOXP3 $(+)$ regulatory $\mathrm{T}$-cells are associated with recurrence in pathologic stage INSCLC patients. Cancer. 2006; 107:2866-2872.

22. Al-Shibli KI, Donnem T, Al-Saad S, Persson M, Bremnes RM and Busund LT. Prognostic effect of epithelial and stromal lymphocyte infiltration in non-small cell lung cancer. Clinical Cancer Research. 2008; 14:5220-5227.

23. Kawai O, Ishii G, Kubota K, Murata Y, Naito Y, Mizuno T, Aokage K, Saijo N, Nishiwaki Y, Gemma A, Kudoh S and Ochiai A. Predominant infiltration of macrophages and CD8(+) T Cells in cancer nests is a significant predictor of survival in stage IV nonsmall cell lung cancer. Cancer. 2008; 113:1387-1395.

24. Ruffini E, Asioli S, Filosso PL, Lyberis P, Bruna MC, Macri L, Daniele L and Oliaro A. Clinical Significance of Tumor-Infiltrating Lymphocytes in Lung Neoplasms. Annals of Thoracic Surgery. 2009; 87:365-372.

25. Al-Shibli K, Al-Saad S, Andersen S, Donnem T, Bremnes RM and Busund LT. The prognostic value of intraepithelial and stromal CD3-, CD117- and CD138-positive cells in non-small cell lung carcinoma. APMIS. 2010; 118:371-382.

26. Dai F, Liu L, Che G, Yu N, Pu Q, Zhang S, Ma J, Ma L and You Z. The number and microlocalization of tumor-associated immune cells are associated with patient's survival time in non-small cell lung cancer. BMC Cancer. 2010; 10.

27. Shimizu K, Nakata M, Hirami Y, Yukawa T, Maeda A and Tanemoto K. Tumor-infiltrating Foxp3+ regulatory $\mathrm{T}$ cells are correlated with cyclooxygenase- 2 expression and are associated with recurrence in resected non-small cell lung cancer. Journal of Thoracic Oncology. 2010; 5:585-590.

28. da Costa Souza P, Parra ER, Atanazio MJ, da Silva OB, Noleto GS, Ab'saber AM, de Morais Fernezlian S, Takagaki $\mathrm{T}$ and Capelozzi VL. Different morphology, stage and treatment affect immune cell infiltration and long-term outcome in patients with non-small-cell lung carcinoma. Histopathology. 2012; 61:587-596.
29. Ilie M, Hofman V, Ortholan C, Bonnetaud C, Coelle C, Mouroux J and Hofman P. Predictive clinical outcome of the intratumoral CD66b-positive neutrophil-to-CD8-positive $\mathrm{T}$-cell ratio in patients with resectable nonsmall cell lung cancer. Cancer. 2012; 118:1726-1737.

30. Kayser G, Schulte-Uentrop L, Sienel W, Werner M, Fisch P, Passlick B, Zur Hausen A and Stremmel C. Stromal CD4/CD25 positive T-cells are a strong and independent prognostic factor in non-small cell lung cancer patients, especially with adenocarcinomas. Lung Cancer. 2012; 76:445-451.

31. Tao H, Mimura Y, Aoe K, Kobayashi S, Yamamoto H, Matsuda E, Okabe K, Matsumoto T, Sugi K and Ueoka H. Prognostic potential of FOXP3 expression in non-small cell lung cancer cells combined with tumor-infiltrating regulatory T cells. Lung Cancer. 2012; 75:95-101.

32. Hald SM, Bremnes RM, Al-Shibli K, Al-Saad S, Andersen $\mathrm{S}$, Stenvold H, Busund LT and Donnem T. CD4/CD8 coexpression shows independent prognostic impact in resected non-small cell lung cancer patients treated with adjuvant radiotherapy. Lung Cancer. 2013; 80:209-215.

33. Hasegawa T, Suzuki H, Yamaura T, Muto S, Okabe N, Osugi J, Hoshino M, Higuchi M, Ise $\mathrm{K}$ and Gotoh $\mathrm{M}$. Prognostic value of peripheral and local forkhead box p3+ regulatory $\mathrm{T}$ cells in patients with non-small-cell lung cancer. Molecular and Clinical Oncology. 2014; 2:685-694.

34. Tao H, Shien K, Soh J, Matsuda E, Toyooka S, Okabe K and Miyoshi S. Density of Tumor-Infiltrating FOXP3+T Cells as a Response Marker for Induction Chemoradiotherapy and a Potential Prognostic Factor in Patients Treated with Trimodality Therapy for Locally Advanced Non-Small Cell Lung Cancer. Annals of Thoracic and Cardiovascular Surgery. 2014; 20:980-986.

35. Djenidi F, Adam J, Goubar A, Durgeau A, Meurice G, de Montpreville V, Validire P, Besse B and Mami-Chouaib F. CD8+CD103+ Tumor-Infiltrating Lymphocytes Are Tumor-Specific Tissue-Resident Memory T Cells and a Prognostic Factor for Survival in Lung Cancer Patients. Journal of immunology (Baltimore, Md : 1950). 2015; 194:3475-3486.

36. Donnem TP, Hald SM, Paulsen EE, Richardsen E, Al-Saad S, Kilvaer TK, Brustugun OT, Helland AP, Lund-Iversen M, Poehl M, Olsen KE, Ditzel HJ, Hansen O, Al-Shibli KI, Kiselev Y, Sandanger TM, et al. Stromal CD8+ T Cell Density - A Promising Supplement to TNM staging in Non-Small Cell Lung Cancer. Clin Cancer Res. 2015;21:2635-43.

37. Schalper KA, Brown J, Carvajal-Hausdorf D, McLaughlin J, Velcheti V, Syrigos KN, Herbst RS and Rimm DL. Objective measurement and clinical significance of TILs in non-small cell lung cancer. J Natl Cancer Inst. 2015; 107.

38. Tian C, Lu S, Fan Q, Zhang W, Jiao S, Zhao X, Wu Z, Sun $\mathrm{L}$ and Wang L. Prognostic Significance of Tumor-infiltrating $\mathrm{CD} 8(+)$ or $\mathrm{CD} 3(+) \mathrm{T}$ Lymphocytes and Interleukin-2 
Expression in Radically Resected Non-small Cell Lung Cancer. Chinese Medical Journal. 2015; 128:105-110.

39. Horne ZD, Jack R, Gray ZT, Siegfried JM, Wilson DO, Yousem SA, Nason KS, Landreneau RJ, Luketich JD and Schuchert MJ. Increased levels of tumor-infiltrating lymphocytes are associated with improved recurrence-free survival in stage 1A non-small-cell lung cancer. The Journal of surgical research. 2011; 171:1-5.

40. Kilic A, Landreneau RJ, Luketich JD, Pennathur A and Schuchert MJ. Density of tumor-infiltrating lymphocytes correlates with disease recurrence and survival in patients with large non-small-cell lung cancer tumors. The Journal of surgical research. 2011; 167:207-210.

41. Nishikawa H and Sakaguchi S. Regulatory T cells in tumor immunity. International journal of cancer. 2010; 127:759-767.

42. deLeeuw RJ, Kost SE, Kakal JA and Nelson BH. The prognostic value of FoxP3+ tumor-infiltrating lymphocytes in cancer: a critical review of the literature. Clinical cancer research. 2012; 18:3022-3029.

43. Nishikawa H, Jager E, Ritter G, Old LJ and Gnjatic S. $\mathrm{CD} 4+\mathrm{CD} 25+$ regulatory $\mathrm{T}$ cells control the induction of antigen-specific CD4+ helper $\mathrm{T}$ cell responses in cancer patients. Blood. 2005; 106:1008-1011.

44. Topalian SL, Hodi FS, Brahmer JR, Gettinger SN, Smith DC, McDermott DF, Powderly JD, Carvajal RD, Sosman JA, Atkins MB, Leming PD, Spigel DR, Antonia SJ, Horn L, Drake CG, Pardoll DM, et al. Safety, activity, and immune correlates of anti-PD-1 antibody in cancer. The New England journal of medicine. 2012; 366:2443-2454.

45. Champiat S, Ileana E, Giaccone G, Besse B, Mountzios G, Eggermont A and Soria JC. Incorporating immune-checkpoint inhibitors into systemic therapy of NSCLC. Journal of thoracic oncology. 2014; 9:144-153.
46. Siegel RL, Miller KD and Jemal A. Cancer statistics, 2015. CA Cancer J Clin. 2015; 65:5-29.

47. Liberati A, Altman DG, Tetzlaff J, Mulrow C, Gotzsche PC, Ioannidis JP, Clarke M, Devereaux PJ, Kleijnen J and Moher D. The PRISMA statement for reporting systematic reviews and meta-analyses of studies that evaluate healthcare interventions: explanation and elaboration. BMJ (Clinical research ed). 2009; 339:b2700.

48. Tierney JF, Stewart LA, Ghersi D, Burdett S and Sydes MR. Practical methods for incorporating summary time-toevent data into meta-analysis. Trials. 2007; 8:16.

49. Parmar MK, Torri V and Stewart L. Extracting summary statistics to perform meta-analyses of the published literature for survival endpoints. Statistics in medicine. 1998; 17:2815-2834.

50. Higgins JP, Thompson SG, Deeks JJ and Altman DG. Measuring inconsistency in meta-analyses. BMJ (Clinical research ed). 2003; 327:557-560.

51. DerSimonian R and Laird N. Meta-analysis in clinical trials. Controlled clinical trials. 1986; 7:177-188.

52. Mantel N and Haenszel W. Statistical aspects of the analysis of data from retrospective studies of disease. Journal of the National Cancer Institute. 1959; 22:719-748.

53. Peters JL, Sutton AJ, Jones DR, Abrams KR and Rushton L. Contour-enhanced meta-analysis funnel plots help distinguish publication bias from other causes of asymmetry. Journal of clinical epidemiology. 2008; 61:991-996.

54. Begg CB and Mazumdar M. Operating characteristics of a rank correlation test for publication bias. Biometrics. 1994; 50:1088-1101.

55. Egger M, Davey Smith G, Schneider M and Minder C. Bias in meta-analysis detected by a simple, graphical test. BMJ (Clinical research ed). 1997; 315:629-634. 